\title{
Covid-19 Korkusu, Kişilik Özellikleri, İş Performansı ve İşten Ayrılma Niyeti Arasındaki Yordayıcı İlişkilerin İncelenmesi
}

DOI: 10.26466/opus.890502

\author{
Büşra Yiğitol * - Saniyebengisu Büyükmumcu ** \\ * Arş. Gör., Konya Gıda ve Tarım Üniversitesi Konya/Türkiye \\ E-Posta: busra.yigitol@gidatarim.edu.tr \\ ORCID: $\quad \underline{0000-0002-7846-3393}$ \\ ** Arş. Gör., Konya Gıda ve Tarım Üniversitesi Konya/Türkiye \\ E-Posta: bengisuyesilyurt@gmail.com \\ ORCID: $\quad$ 0000-0003-4253-7159
}

$\ddot{O} z$

Covid-19 (Yeni Koronavirüs) salgin sürecinde en büyük değişikliklerin yaşandiğl alanlardan biri çalışma hayatı olmuştur. Bu süreçte birç̧ok sektörde esnek çalışma sistemine geçilmiş, ardından normalleşme dönemi ile birlikte kimi işyerleri aktif mesaiye başlamış, diğer bazı işletmeler dönüşümlü veya hibrit çalışma sistemleri benimsemiştir. Pandemi sırasında bulaş riskine ră̆men, belirli sektörlerde çalışanlar daha da sıkı bir şekilde çalışmaya devam etmek zorunda kalmışlardır. Covid-19 salgınının işyerlerine olan etkisi sadece mesai saatleri ve iş yapma şekilleri ile sınırl kalmamış, aynı zamanda çalışanlarm işe karşı tutumlarm etkiler hale gelmiştir. Bu doğrultuda bu araştırmanın amacı, çalışanların Covid-19 korkusu, kişilik özellikleri, iş performansları, işten ayrılma niyetleri arasındaki yordayıcı ilişkileri belirlemektir. Online olarak toplanan verilerin analizinde yapısal eşitlik modellemesi için Amos 21 programından yararlanılmıştır. Araştırma sonucunda çalışanların Covid-19 korkusunun işten ayrılma niyetini etkilediği ancak iş performansına anlamlı bir etkisinin olmadığı sonucuna ulaşılmıştır. Ayrica Covid-19 korkusunun çalışanlarm nevrotik ve sorumluluk kişilik özellikleri ile kuvvetlendiği görülmektedir. Mevcut çalışma Covid-19 sürecinde çalışanların Covid-19 nedeniyle değiş̧en iş yaşamı ile başa çıkmaları için önemli sonuçlar ortaya koymaktadır.

Anahtar Kelimeler: Covid-19 Korkusu, Kişilik Özellikleri, Iş Performansı, Işten Ayrılma Niyeti 


\title{
Analysis of the Relationships Between Fear of Covid-19, Personality Traits, Job Performance and Turnover Intention
}

\begin{abstract}
Business life have been experiencing devastating changes and challenges due to Covid-19 (New Coronavirus) pandemic. In this period, flexible working systems have been adopted in many sectors, then some workplaces have started to work actively with the normalization period, where some others have adopted hybrid working systems. Despite the risk of transmission during the pandemic, employees working in specific sectors had to continue to work even harder. The impact of the Covid-19 pandemic on workplaces is not only limited with changing work hours and ways of doing business. It also has impact on employees' attitude towards their jobs. In this regard, the purpose of this study is to determine the effect of fear caused by Covid-19 on employees' job performance and turnover intention, by considering their personality traits. Then the data collected online was analyzed by structural equation modeling via Amos 21 software. The results of the study reveal that, the employees' fear of Covid-19 affects their turnover intention but not their job performance. It can be stated that neurotic and responsible personality traits of employees increase the fear of Covid-19. The current study reveals important results for employees and managers to cope with changing working conditions due to Covid-19.
\end{abstract}

Keywords: Fear Of Covid-19, Personality Traits, Job Performance, Turnover Intention 


\section{Giriş}

Son dönemlerde yaşanan birçok gelişme iş dünyasındaki rekabetin boyutlarını değiştirmiştir. Değişen rekabet koşulları işletmelerin hayatta kalabilmeleri için daha fazla çaba sarf etmeleri ve sahip oldukları kaynakları bu doğrultuda daha etkin kullanmalarını gerektirmektedir. İnsan kaynağı, bu açıdan bakıldığında işletmelerin rekabette kullanabileceği önemli kaynaklarından bir tanesi olup göstereceği yüksek iş performansı ile rekabet şartlarında işletmelerin başarılı olabilmesinde etkilidir. Bu nedenle iş performansını artırmak için gerekli olan ortamın sağlanması önemlidir. Campbell (1990), iş performansının tek bir eylem olmadığını, daha ziyade "karmaşık bir aktivite" olduğunu belirtir. Bu sebeple performansın tek bir belirleyicisinin olduğunu söylemek mümkün değildir. Bilişsel veya zihinsel yetenekler, motivasyon, bireysel çaba gibi birçok tetikleyici iş performansı etkileyen unsurlar arasında yer almaktadır. Ayrıca çalışanların performansları ekonomik faktörlerin yanı sıra sosyal değişkenler tarafından da etkilenmektedir. Dolayısıyla tüm değişkenler çalışan performanslarını etkilemekte ve dolaylı yoldan işletme başarısına da etki sağlamaktadır. Bu açıdan işletmeler, çalışanların performanslarına olumlu ya da olumsuz etki eden faktörleri belirlemek, olumsuzları ortadan kaldırmak, olumluları ise daha fazla geliştirmek durumundadır.

Son dönemlerde çalışan performansını etkileyebileceği düşünülen en önemli faktörlerden bir tanesi de Covid-19 (Yeni Korona virüs) salgınıdır. Covid-19, MERS ve SARS gibi ciddi solunum sıkıntısına sebebiyet verebilen soğuk algınlığına bağlı olarak gelişen Betacoronavirus cinsi içindeki Sarbecovirus altcinsi altında yer alan bir virüs türüdür. (T.C. Sağlık Bakanlığı, 2020). Covid-19 damlacık yolu ile bulaşan, bireylerin öksürme, hapşırma yoluyla etrafa yaymış oldukları damlacıkların başka kişilerce temas etmesi ve ağız, burun ve göz aracılığıyla vücut içerisine alınması ile çoğalan bir salgındır (T.C. Sağlık Bakanlığı, 2020). 31 Aralık 2019'da Çin'in Vuhan şehrinde ortaya çıkan ve daha sonra tüm dünyada yayılım gösteren Covid-19 ile ilgili dünya genelinde vaka sayısına bakıldığında 4 Aralık 2020 tarihi itibariyle 65 milyondan fazla kişinin virüse yakalandığı, 1 milyon 500 bin kişinin ise Covid-19 sebebiyle yaşamını yitirdiği görülmektedir (Worldometers, 2020). Ülkemizde ise 11 Mart 2020' de ilk vaka görülmüştür. Toplamda 733 bini geçkin vaka sayısı gözlenmiştir. Ülke genelinde salgın kaynaklı vefat eden kişilerin sayısı 
ise 14 bin kişiyi geçmiş bulunmaktadır. Hem dünya genelinde hem de ülkemizde gerek vaka sayısı gerek ise ölüm sayısı gün geçtikçe artış göstermektedir. Dolayısıyla Covid-19 salgını hem ulusal hem küresel boyutta etki gösteren ve her iki boyutta da kapsamlı önlemlerin alınmasını gerektiren ciddi bir konu olarak karşımıza çıkmaktadır.

Ulusal çapta karar merkezlerinin konu ile ilgili izleyecekleri politikalar, belirlenen kısıtlar ve tedbir uygulamaları bu noktada önemli bir adım olmaktadır. Salgın ile mücadelede devletlerin yürüttügü politikalar ve müdahaleler şüphesiz hayatın normal sürece bir an önce dönebilmesinde bir gerekliliktir. Buna yönelik olarak Şekil 1, ülkemizin salgın sürecinde, başta okulların kapatılması, işyerlerinin kapatılması ve seyahat yasakları olmak üzere almış olduğu tedbirleri içeren ve devletin bu konudaki müdahale derecesini gösteren bir ölçüt sunmaktadır. Buna göre 0 ile 100 puan aralığında bir değerlendirme üzerinden ülkemiz mart ve mayıs ayları arası salgın ile mücadelede müdahaleci bir politika izlerken Ağustos ayı itibariyle izlediği sıkı politikaları gevşettiği görülmektedir. Dünya genelinde birçok ülke için bu müdahale indeks sonuçları ayrı ayrı değerlendirilebilmektedir. Ancak genel olarak elde edilecek sonuç tüm ülkelerde az ya da çok salgın ile mücadelede devletlerin yoğun uğraş gösterdiğini işaret etmektedir. Bunun en temel sebepleri arasında Covid-19 un sadece sağlık ile ilgili bir problem oluşturmaması aynı zamanda ekonomi, iş hayatı ve sosyal hayat açısından da yaşantımıza temas etmiş olmasidir.

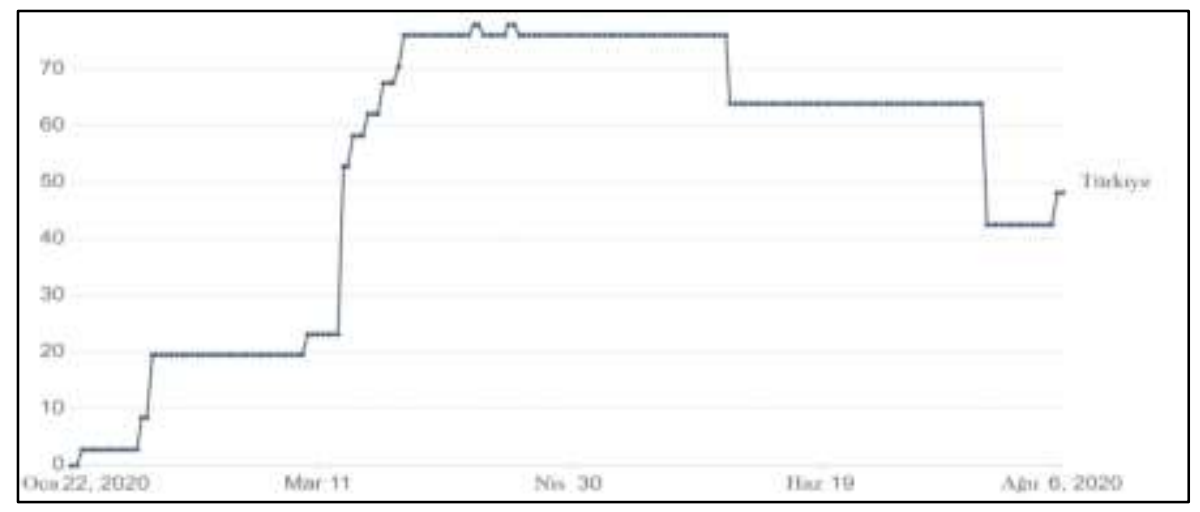

Şekil 1. Salgin ile ilgili devlet müdahale endeksi Our World in Data (2020). 
Covid-19, birçok yönden hayatımızda değişimlere sebep olmuş ve salgın ile mücadele sürecinde alınan tedbirler birçok sistemin işleyişini etkileyerek yeni bir düzen içerisinde işlerin yürütülmesini gerekli kılmıştır. Dünyanın dört bir yanındaki ülkeler, katlanarak artan yayılmayı kontrol altına almak için bir dizi koruyucu önlem almak durumunda kalmıştır (Nicola vd, 2020).

Salgının ekonomik açıdan etkilerine bakıldığında istihdam, gelir kaybı, üretimin durma noktasına gelmesi gibi birçok negatif etkiler karşımıza çıkmaktadır. Ekonomik faaliyetlerde yaşanan keskin düşüşlerin en önemli sebepleri arasında işyerlerinin kapatılması gelmektedir. Şekil 2' de dünyada istihdam edilen nüfusun, iş yeri kapatmanın zorunlu ve esnek olduğu ülkelerde yaşayan kısmına yönelik bir gösterge sunulmaktadır. Bu göstergeye göre dünyada istihdam edilen nüfusun çoğunluğunun işyeri kapatma zorunluluğu olan ülkelerde çalıştığı görülmektedir.

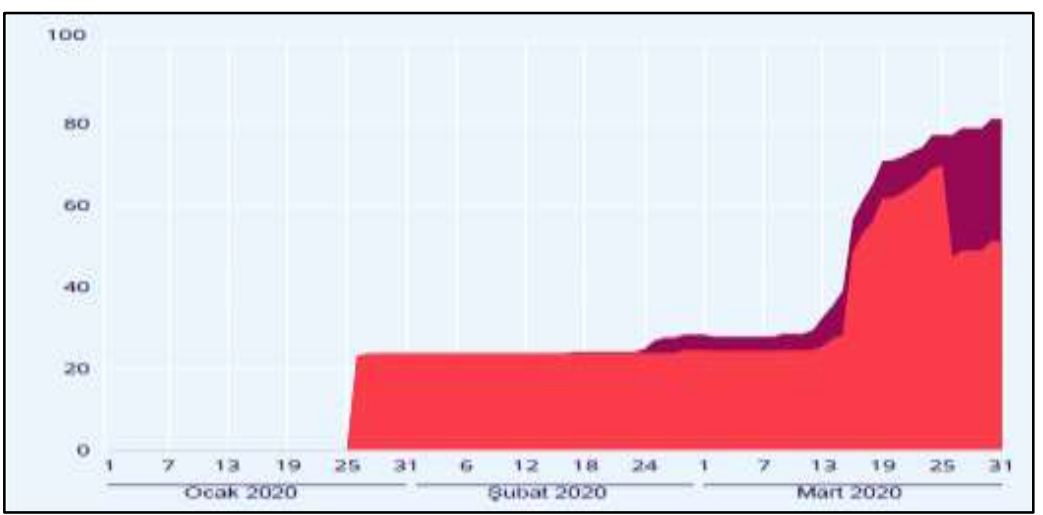

Dünyada istihdam edilen nüfusun, işyeri kapatmasının esnek olduğu ülkelerde yaşayan kısmı Dünyada istihdam edilen nüfusun, işyeri kapatmasının zorunlu olduğu ülkelerde yaşayan kısmı

Şekil 2: Dünyada istihdam edilen nüfusun, işyeri kapatmanın zorunlu ve esnek olduğu ülkelerde yaşayan kısmına yönelik bir gösterge. ILO, (2020)

Özellikle sektörel etkiler incelendiğinde birçok sektörün bu salgın sürecinden olumsuz etkilendiği görülmektedir. Tarım sektöründe tarımsal emtia fiyatlarının salgın öncesine göre \%20 oranında azaldığı görülmektedir (Bhosale, 2020). Seyahat sektöründe sosyal mesafe uygulamaları kaynaklı ciddi bir azalma yaşanmıştır. Özellikle ülke sınırlarının kapatılması ve uluslararası ve ulusal seyahatlerin yasaklanması birçok firmayı ekonomik açıdan etkilemek- 
tedir. Seyahat kısıtlaması ile bağlantılı olarak turizm sektörü de salgın sürecinden olumsuz etkilenen sektörler arasında yer almıştır. Salgın ile ilgili en büyük etkiyi yaşayan sektörlerden bir tanesi de sağlık sektörü olmuştur. Sağlık sektörü hem arz hem de talep açısından sıkıntı yaşamaktadır. Eğitim sektöründe ise okulların kapatılması ya da eğitimin bölgesel olarak yürütülmesi, dünya öğrenci nüfusunun \%60'ından fazlasını etkilemektedir (UNESCO, 2020). Genel olarak bakıldığında fabrikaların kapanması, karantina kısıtlamaları, evden çalışma uygulaması ve kişilerin bireysel olarak uyguladıkları kısıtlamalar hem üretimi hem de talebi azaltan sonuçlara sebebiyet vermektedir. Yaşanan tedirginlik iş hayatına da yansımakta ve bu alanda yeni çözümler geliştirilmektedir (Wren-Lewis, 2020). Bu süreçte birçok iş yeri, insan kaynakları uygulamalarını online olarak yürütmeye devam ederek uzaktan çalışma sistemleri ile birlikte değişen görev tanımları ve sorumluluklara uyum sağlamak için çabalamıştır (Akbaş-Tuna ve Çelen, 2020).

Ülkemizde 1 Haziran itibariyle kademeli olarak normal hayata geçiş başlatılmış ve birçok işyeri yeniden faaliyetlerine devam edebilmek için kapılarını açmıştır. Ancak salgının yayılımının hala kontrol altına tam olarak alınamaması normal hayata geçiş sürecinde birtakım tedirginlikler oluşturmuştur. Örneğin, Covid-19 salgın sürecinde işe yeniden başlayan çalışanların yaklaşık \%20'sinde anksiyete, depresyon veya uykusuzluk semptomları (Zhang vd, 2020), yaklaşık \%10'unda ise travma sonrası stres bozukluğu (Tan vd, 2020) görülmüştür. Dolayısıyla Covid-19 sürecinde evden, uzaktan ya da esnek bir şekilde çalışan kişilerin normal çalışma düzeni ile işe yeniden başlamasının, önemli bir stres faktörü haline geldiği söylenebilir. Covid- 19 virüsü, bulaş hızı ve ölüm riski ile bireylerin psikolojik olarak kendilerini rahatsız ve huzursuz hissetmesine sebep olabilmekte, bu da Covid-19 korkusunu ortaya çıkarmaktadır (Yakut, Kuru ve Güngör, 2020). Bu süreçte bireylerin iş güvensizliği ve korona virüse yönelik yüksek bir korku yaşamasının, depresif belirtilerle ilişkili olduğu bilinmektedir (Gasparro vd, 2020). Bu doğrultuda iş yerlerinin korona virüs tedbirlerine uymaması, işin devamına yönelik duyulan güvensizlik, yüksek düzeyde Covid-19 korkusu gibi faktörlerin bu süreçte bireylerin psikolojik sağlı̆̆ını tehdit ettiği ve bireylerin işle ilgili durumları daha stresli olarak değerlendirmesine yol açtı̆̆ söylenebilir. Bu durumun minimize edilmesi için yapılacak olan çalışmalar, işyerlerine de ayrı bir sorumluluk yüklemektedir. İşyerleri faaliyetlerine devam ederken aynı za- 
manda salgın ile mücadelede birtakım tedbirleri hayata geçirmek durumunda kalmaktadırlar. Covid-19 sürecinde iş yerlerinde korona virüse yönelik yüksek düzeyde önlemlerin alınması, çalışanların psikolojik sıkıntılarını azaltan ve iş performanslarını arttıran önemli bir faktördür (Sasaki, Kuroda, Tsuno ve Kawakami, 2020).

İşyerlerindeki tedbirler haricinde çalışanlar da kişisel olarak aldıkları birtakım önlemler ile salgın sürecinde kendilerini koruma eğilimi içerisine girmektedir. İssyerlerinde alınan kurumsal veya bireysel tedbirlere rağmen Covid-19 kaynaklı endişe ve korkuların, çalışanların iş performansı üzerinde olumsuz etkiye sahip olması beklenmekte olup, bazı durumlarda bu korkunun çalışanın iş yaşamının sürekliliğini tehdit eder hale gelmesi olası gözükmektedir. Alınan kişisel ve kurumsal tedbirlere uyum konusundaki hassasiyet her bireyde farklılık gösterebilmektedir. Bunun en temel sebepleri arasında her bireyin farklı kişilik özelliklerine sahip olmasıdır. Bazı kişiler korku ve kaygıyı diğer kişilere göre daha yoğun yaşayabilmekte, kurallara uyum konusunda daha hassas olabilmekte ya da benzer durumlarda farklı tepkiler verebilmektedir.

Özetle Covid-19 un başta ekonomik, psikolojik ve sosyal olmak üzere birçok açıdan hayatımızı etkilediği görülmektedir. Özellikle çalışanlar ve işletmeler açısından konunun ele alınması, mevcut durumun saptanması ve çözüme yönelik stratejilerin geliştirilebilmesi önem taşımaktadır. Tüm bu değerlendirmeler ışığında bu çalışmanın amacı salgın ile mücadele sürecinde çalışanların yaşadığı Covid-19 kaynaklı korkuları, kişilik özellikleri, iş performansları ve işten ayrılma niyetleri arasındaki yordayıcı ilişkileri araştırmaktır. Araştırma sonucunda Covid-19 sürecinde çalışma yaşamına ilişkin önemli tespitlerin ortaya konulacağı düşünülmektedir.

\section{Literatür Taraması}

Araştırmanın amacına uygun olarak literatürde konu ile ilgili yapılan çalışmalar incelenmiştir. Bu bağlamda çalışanlara ve işverenlere yönelik olarak yürütülen performans, çalışma düzeni, işverenlerin salgın sürçendeki durumları, sektörel etkiler gibi konular ele alınarak tarama yapılmıştır. Literatürde korku ve kişilik ile ilgili yapılmış çalışmalar da taranmıştır. Elde edilen çalışmaların özet bilgileri Tablo 1'de derlenmiştir. 
Tablo 1. Literatür taraması özet bilgi

ILO (2020b) Çalışmada salgın ile ilgili virüs pozitif tanısı henüz konulmamış ancak salgının şiddetli olarak yaşandığı bölgelerde ikamet eden kişiler ile yapılan anket çalışmasının sonuçlarına yer verilmiştir. Çalışma sonuçlarına göre katılımcıların yarıdan fazlasının salgın sürecinde işlerine devam ettiği bu kişilerin çoğunluğunun evden çalışma uygulamasına geçtiği belirtilmiştir. Katılımcıların önemli bir kısmı ise salgın sürecinde işlerine ara verdiğini belirtmiştir. Salgın sırasında işinden ayrılan katılımcıların sayısı ise düşük bir orandadır.

ILO (2020a) Raporda salgın sürecinde çalışma yaşamına ilişkin istatistikleri içermektedir. Rapor sonuçlarına göre 2020 yılının Nisan ayından itibaren çalışma sürelerinde \%6,7 civarında bir azalma yaşanabileceği belirtilmiştir. Salgın sürecinin dünya genelinde işgücünün \%81'ini etkilediği belirtilmiştir. Raporda sektörler açısından bir karşılaştırma da yapılmıştır.

Deloitte (2020) Raporda salgın sürecinde dijitalleşme sürecinin kolaylaştırıcı etkileri ele alınmıştır. Salgın ile mücadele sürecindeki karantina uygulamaları sebebiyle birçok işletmenin faaliyetlerini yavaşlatması hatta durdurması söz konusu iken bazılarının ticari faaliyetlerini dijital ortamlar aracılığıyla yürütmeye devam ettiği rapor sonuçları aralarında yer almaktadır.

\begin{tabular}{|c|c|}
\hline Mckinsey (2020) & $\begin{array}{l}\text { Raporda Amerikalıların \%62'sine yakınının salgın sırasında evden çalışma uygulama- } \\
\text { sını kullandığı görülmektedir. Salgın öncesi dönem ile kıyaslandığında bu oran ol- } \\
\text { dukça yüksek olarak değerlendirilmiştir. }\end{array}$ \\
\hline $\begin{array}{l}\text { Haleem, Javaid, } \\
\text { Vaishya (2020) }\end{array}$ & $\begin{array}{l}\text { Çalışma sonuçları incelendiğinde salgın sürecinin ekonomik açıdan olumsuz sonuç- } \\
\text { ları arasında üretim süreçlerinin sekteye uğraması, tedarik zinciri ağısında aksaklıkla- } \\
\text { rın yaşanması, nakit akışlarında zayıflık, gelir artışında yavaşlamama durumlarının } \\
\text { yer aldığı görülmektedir. }\end{array}$ \\
\hline ILO (2020b) & $\begin{array}{l}\text { Raporda, salgının ekonomik etkileri incelenmiş ve dünya genelinde birçok sektörün, } \\
\text { özellikle küçük ve orta ölçekli işletmelerin faaliyetlerini yürütmede zorlandığı belirtil- } \\
\text { miştir. Ayrıca milyonlarca insanın hem gelir hem de iş kaybına yönelik risk ile karşı } \\
\text { karşıya kaldığı da belirtilmiştir. }\end{array}$ \\
\hline Nicola vd (2020) & $\begin{array}{l}\text { COVID-19'un sosyo-ekonomik etkilerini belirtilmektedir. Gıda, eğitim, imalat, turizm, } \\
\text { seyahat ve sağlık sektörleri üzerinden salgın sürecinin etkileri belirtilmiştir. }\end{array}$ \\
\hline $\begin{array}{l}\text { Öngel, Tatlı ve } \\
\text { Bozkurt (2020) }\end{array}$ & $\begin{array}{l}\text { Çalışmada kişilik özelliklerine göre bireylerin, Covid-19 sürecinde paylaşılan sosyal } \\
\text { medya içeriklerini algılama şeklinin değiştiği bulunmuştur. Dişadönüklük ve sorum- } \\
\text { luluk kişilik özelliğine sahip bireylerin, Covid-19 gibi küresel kriz durumlarına ilişkin } \\
\text { paylaşımlardan daha az korktuğu, ayrıca Covid-19 korkusunun depresif ruh hali ile } \\
\text { ilişkili olduğu ortaya koyulmuştur. }\end{array}$ \\
\hline $\begin{array}{l}\text { Garbe, Rau ve } \\
\text { Toppe (2020) }\end{array}$ & $\begin{array}{l}\text { Çalışmada nevrotiklik kişiliközelliği taşıyan bireylerin Covid-19 salgınına ilişkin daha } \\
\text { büyük bir tehdit algıladığl; sorumluluk kişilik özelliğine sahip bireylerin ise daha sık } \\
\text { alışverişe ve stokçuluğa yöneldiği ortaya koyulmuştur. }\end{array}$ \\
\hline $\begin{array}{l}\text { Carvalho, Pia- } \\
\text { nowski ve Gon- } \\
\text { çalves }(2020)\end{array}$ & $\begin{array}{l}\text { Dışadönük kişilik özelliği taşıyan bireylerin Covid-19 sürecinde sosyal mesafe kural- } \\
\text { larına daha az uyduğu, sorumluluk kişilik özelliğine sahip bireylerin ise sosyal mesafe } \\
\text { ve el yıkama tedbirlerine daha bağlı olduğu görülmüştür. }\end{array}$ \\
\hline Sasaki vd (2020) & $\begin{array}{l}\text { Bir şirketin Covid-19 virüsüne ilişkin aldığı tedbirler arttıkça, çalışanların Covid-19 } \\
\text { korkusunun arttı̆̆ı bulunmuştur. Ayrıca iş ortamında tedbirlerin artırılması, çalışan- } \\
\text { ların iş performanslarını artırmada ve psikolojik sıkıntılarını azaltmada etkilidir. }\end{array}$ \\
\hline $\begin{array}{l}\text { Irshad, Khattak, } \\
\text { Hassan, Majeed } \\
\text { ve Bashir (2020) }\end{array}$ & $\begin{array}{l}\text { Çalışma yaşamında Covid-19 kaynaklı iş yükü artan alanlardan biri olan sağlık sektö- } \\
\text { ründe yürütülen bu araştırmada sağlık sektörü çalışanlarında Covid-19 korkusunun } \\
\text { psikolojik sıkıntıları artırdığı, bunun da işten ayrılma niyetine yol açtığı belirtilmiştir. }\end{array}$ \\
\hline
\end{tabular}




\section{Yöntem}

Çalışmada Covid-19 korkusu, kişilik özellikleri, iş performansı ve işten ayrılma niyeti arasındaki yordayıcı ilişkileri belirlemek amaçlanmıştır. Bu amaç doğrultusunda yürütülen çalışma, ilişkisel tarama türünde nicel bir araştırmadır. Çalışmada veriler online olarak, Türkiye' de normalleşme sürecine geçiş adımlarının atıldığı Haziran ve Temmuz aylarında toplanmıştır. Veri toplama setinde çalışmaya katılım kriterinin hâlihazırda bir işte çalışmak olduğu belirtilmiştir. Ayrıca çalışmanın Etik Kurul İzni olduğu ve katılımda gönüllülügün esas alındığı, istendiği zaman çalışmadan ayrılabileceği konusunda bilgilendirme yapılmıştır. Bu doğrultuda 547 çalışan bireyden veri toplanmıştır. Eksik ya da yanlış doldurduğu belirlenen 5 veri çalışma dışında tutularak Yapısal Eşitlik Modeli (YEM) analizinde 542 veri modele dâhil edilmiştir. Kullanılan veri toplama araçlarına ilişkin bilgiler aşağıda yer almaktadır.

İş Performansı Ölçeği: Çalışanların iş performansını belirlemek için Sigler ve Pearson (2000)' in çalışmasında kullanmış olduğu ölçekten yararlanılmıştır. İş performansını ölçen 4 ifade bulunmaktadır. Ölçeğin güvenilirlik kat sayısı 0.87 olarak hesaplanmıştır.

İşten Ayrılma Niyeti Ölçeği: İşten ayrılma niyetini ölçmek için kullanılan ölçek Kaya'nın (2016) kullanmış olduğu ölçekten yararlanılmıştır. Ölçeğin güvenilirlik katsayısı 0.81 olarak hesaplanmıştır. Ölçek 3 maddeden oluşmaktadir.

Covid-19 Korkusu Ölçeği: Çalışmada bireylerin Covid-19 korkularını belirlemek amacıyla Haktanır, Seki ve Dilmaç (2020) tarafından Türkçe 'ye uyarlanan Covid-19 korkusu ölçeği kullanılmıştır. Ölçek tek boyutlu olup toplamda 7 maddeden oluşmaktadır. Ölçeğin güvenilirlik kat sayısı 0.87 olarak hesaplanmıştır.

Beş Faktör Kişilik Ölçeği: Çalışmada bireylerin kişilik özelliklerini belirlemek amacıyla Sümer ve Sümer (2005) tarafından Türkçe 'ye uyarlanan Beş Faktör Kişilik Ölçeği kullanılmıştır. Beş Faktör Kişilik Ölçeği, 5'li likert tipinde olan bu ölçek, 16'sı ters madde olmak üzere toplamda 44 maddeden oluşmaktadır. Ölçeğin dışadönüklük, nevrotiklik, sorumluluk, uyumluluk ve deneyime açıklık olmak üzere beş alt boyutu bulunmaktadır. Ölçeğin güvenilirlik kat sayısı 0.80 olarak hesaplanmıştır. 
Kişisel Bilgi Formu: Katılımclların demografik bilgilerine ilişkin ifadelerine yer verilmiştir.

Veri toplama araçları ile elde edilen verilerin analizinde betimsel istatistikler için SPSS 25 programı, Yapısal Eşitlik Modeli (YEM) için ise Amos 21 programından yararlanılmıştır. Yapısal eşitlik modeli için iyi uyum ve kabul edilebilir uyum değerleri araştırmacılar tarafından belirlenmiştir (SchermellehEngel, Moosbrugger ve Müller, 2003; Simon vd, 2010). Uyum değerlerinin yüksek olması, modelin kabul edilebilir olduğunu göstermektedir. Bu doğrultuda yapısal eşitlik modellemesi için kabul edilen iyi uyum ve kabul edilebilir uyum değerleri Tablo 2'de sunulmuştur.

Tablo 2. Yapısal eşitlik modellemesi için kabul edilen iyi uyum ve kabul edilebilir uyum değerleri

\begin{tabular}{lll}
\hline Ölçüm & İyi Uyum Değerleri & Kabul Edilebilir Uyum Değerleri \\
\hline$(\mathrm{X} 2 / \mathrm{sd})$ & $\geq 3.00$ & $\leq 5.00$ \\
\hline RMSEA & $\leq 0.05$ & $\leq 0.08$ \\
\hline SRMR & $\leq 0.05$ & $\leq 0.10$ \\
\hline NFI & $\geq 0.95$ & $\geq 0.80$ \\
\hline CFI & $\geq 0.95$ & $\geq 0.85$ \\
\hline GFI & $\geq 0.90$ & $\geq 0.80$ \\
\hline AGFI & $\geq 0.95$ & $\geq 0.85$ \\
\hline TLI & $\geq 0.95$ & $\geq 0.80$ \\
\hline
\end{tabular}

Schermelleh-Engel, Moosbrugger ve Müller, 2003; Simon vd, 2010.

\section{Bulgular}

\section{Demografik bulgular}

Araştırmaya katılan kişilerin demografik bilgilerine ilişkin sonuçlar Tablo 2' de belirtilmiştir. Bu sonuçlara göre katılımcıların \%62.3 ü kadın \%37.7 si erkektir. Yaş dağılımları incelendiğinde 25 ve 44 yaş aralığındaki kişilerin katılımcıların \%60'ından fazlasını oluşturduğu gözükmektedir. Eğitim durumları değerlendirildiğinde ise katılımcıların yarısının lisans mezunu olduğu görülmektedir. Araştırmaya katılan kişilerin yarısından fazlasının evli ve çocuk sahibi olduğu, çoğunun özel sektörde çalıştığı görülmektedir. Özel sektörde çalışan kişilerin neredeyse büyük çoğunluğu hizmet sektöründe çalışırken imalat sektöründe çalışanların sayısının da oldukça fazla olduğu tespit edilmiştir. Bu kişilerin kurumlarındaki personel sayıları değerlendirildiğinde 
katılımcıların yarısından fazlasının 50 ve üzeri çalışana sahip kurumlarda istihdam edildiği görülmektedir. Katılımcıların çalışma süreleri değerlendirildiğinde 10 yıldan fazla aynı kurumda çalışanların oranının \%29, 8, 1-3 yıl arasında aynı kurumda çalışanların oranının \%23 olduğu görülmektedir. Genellikle 1 yıldan fazla süredir istihdam edilen kişiler olduğu görülmektedir. Kurum içi pozisyonlar değerlendirildiğinde ise neredeyse \%70'inin mavi yakalı çalışan olduğu görülmektedir.

Tablo 3. Demografik bilgiler

\begin{tabular}{|c|c|c|c|}
\hline & Yanit & Say1 & Yüzde \\
\hline \multirow{2}{*}{ Cinsiyetiniz } & Kadın & 336 & 62,3 \\
\hline & Erkek & 203 & 37,7 \\
\hline \multirow{6}{*}{ Yaşınız } & $15-24$ yaş & 22 & 4,1 \\
\hline & 25 - 34 yaş & 193 & 35,9 \\
\hline & 35 - 44 yaş & 164 & 30,5 \\
\hline & $45-54$ yaş & 120 & 22,3 \\
\hline & $55-64$ yaş & 31 & 5,8 \\
\hline & 65 Yaş ve Üstü & 7 & 1,3 \\
\hline \multirow{6}{*}{ Eğitim Durumunuz } & İlkokul & 11 & 2,0 \\
\hline & Ortaokul & 12 & 2,2 \\
\hline & Lise & 64 & 11,8 \\
\hline & Önlisans & 40 & 7,4 \\
\hline & Lisans & 273 & 50,5 \\
\hline & Lisansüstü & 141 & 26,1 \\
\hline \multirow{2}{*}{ Medeni Durumunuz } & Evli & 374 & 69,3 \\
\hline & Bekar & 166 & 30,7 \\
\hline \multirow{2}{*}{ Çocuk sahibi olma durumu } & Evet & 342 & 63,5 \\
\hline & Hayır & 197 & 36,5 \\
\hline \multirow{2}{*}{ Hangi sektörde çalışıyorsunuz } & Kamu sektörü & 201 & 38,1 \\
\hline & Özel sektör & 327 & 61,9 \\
\hline \multirow{3}{*}{ Özel sektörde hangi sektör dalı } & İmalat & 63 & 19,2 \\
\hline & Tarım & 8 & 2,4 \\
\hline & Hizmet & 257 & 78,4 \\
\hline \multirow{4}{*}{ Çalışan sayısı } & 1-9 kişi & 108 & 33,1 \\
\hline & 10-49 kişi & 46 & 14,1 \\
\hline & 50-249 kişi & 81 & 24,8 \\
\hline & 250 kişi ve üzeri & 91 & 27,9 \\
\hline \multirow{5}{*}{ Kıdem (Aynı Kurumda) } & 1 yildan az & 60 & 11,4 \\
\hline & $1-3$ yıl & 121 & 23,0 \\
\hline & $4-6$ yll & 91 & 17,3 \\
\hline & 7-10 yıl & 98 & 18,6 \\
\hline & 10 yıldan fazla & 157 & 29,8 \\
\hline \multirow{2}{*}{ Kurum içi pozisyon } & Beyaz Yakalı & 159 & 30,2 \\
\hline & Mavi Yakalı & 368 & 69,8 \\
\hline
\end{tabular}




\section{Yapısal Eşitlik Modeline İlişkin Bulgular}

Çalışmada kişilik özellikleri, Covid-19 korkusu, iş performansı ve işten ayrılma niyeti arasındaki yordayıcı ilişkiler incelenmektedir. Bu doğrultuda ilk olarak Covid-19 korkusu, iş performansı ve işten ayrılma niyeti arasındaki yordayıcı ilişkilere yönelik bir model oluşturularak sunulmuştur. İkinci olarak ise kişilik özelliklerinin alt boyutları olan dışadönüklük, sorumluluk, deneyime açıklık, uyumluluk ve nevrotiklik kişilik özellikleri, Covid-19 korkusu ve iş performansı arasındaki yordayıcı ilişkileri belirlemek için modeller oluşturularak her bir kişilik boyutu için ayrı başlıklar halinde sunulmuştur.

\section{Covid-19 Korkusu, İş Performansı Ve İşten Ayrnlma Niyeti Arasındaki Yor-} dayıcı İlişkilere Yönelik Yapısal Eşitlik Modeli

Covid-19 korkusu, iş performansı ve işten ayrılma niyeti arasındaki yordayııı ilişkilere yönelik kurulan modelin uyum indeksi değerleri Tablo $6^{\prime}$ da sunulmuştur. Tablo 6'da yer alan uyum değerleri incelendiğinde X2/sd, RMSEA, SRMR, NFI, CFI, AGFI, TLI ve GFI değerlerinin kabul edilebilir uyum değerlerine karşılık geldiği anlaşılmaktadır. Dolayısıyla bu değerler doğrultusunda yapısal eşitlik modelinin genel olarak, istenen düzeyde uyum değerlerine sahip olduğu anlaşılmaktadır.

Tablo 6. Covid-19 korkusu, iş performansı ve işten ayrılma niyeti arasındaki yordayıcı ilişkilere yönelik yapısal eşitlik modeli uyum değerlerine ilişkin istatistikler

\begin{tabular}{lllllllll}
\hline Ölçüm & $\mathbf{( X 2 / s d )}$ & RMSEA & SRMR & NFI & CFI & GFI & AGFI & TLI \\
\hline $\begin{array}{l}\text { Modelin Uyum } \\
\text { İndeksi Değerleri }\end{array}$ & 3,88 & 0,07 & 0,05 & 0,93 & 0,95 & 0,93 & 0,9 & 0,93 \\
\hline
\end{tabular}

Test edilen ilk modelde, Covid-19 korkusunun işten ayrılma niyeti performansı üzerindeki etkisinde iş performansı değişkeninin aracılık rolü olup olmadığını test etmek amacıyla oluşturulan model Şekil 3'de gösterilmiştir. 


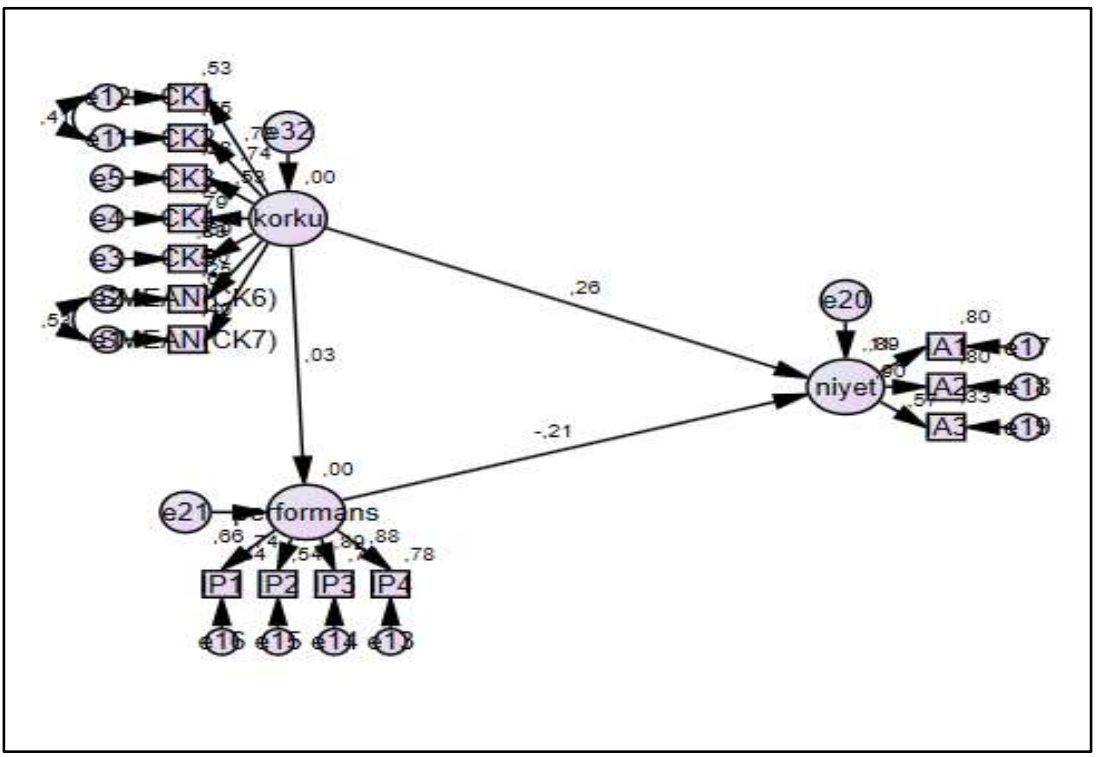

Şekil 3. Covid-19 korkusu, İş Performansı ve İşten Ayrılma Niyeti Arasındaki Yordayıcı İlişkilere Yönelik Yapısal Eşitlik Modeli

Tablo 7. Işten ayrulma niyeti yapısal eşitlik modeli

\begin{tabular}{llllll}
\hline Yol & Katsayı & Std. Katsayı & Std. Hata & $\mathbf{t}$ & $\mathbf{p}$ \\
\hline İş performansı $\leftarrow$ Covid-19 korkusu & .04 & .03 & .07 & .65 & .513 \\
\hline İşten ayrılma niyeti $\leftarrow$ Covid-19 korkusu & .44 & .25 & .08 & 5.18 & $* * *$ \\
\hline İşten ayrılma niyeti $\leftarrow$ İş performansı & -.26 & -.21 & .06 & -4.60 & $* * *$ \\
\hline
\end{tabular}

*Tüm değerlerin anlamlılık düzeyi $\mathrm{p}<.05$ olarak hesaplanmıştır.

Oluşturulmuş olan modelde aracılık rolüne bakmadan önce bağımsız değişkenin bağımlı değişken üzerinde etkisinin olup olmadığı incelenmiştir. Modelde Covid-19 korkusunun iş performansı üzerinde anlamlı bir etkisinin olmadığı görülmektedir ( $\mathrm{t}=.65, \mathrm{p}>0.5)$. Covid-19 korkusunun İşten ayrılma niyetini anlamlı bir şekilde yordadığı görülmektedir ( $\mathrm{t}=5.18, \mathrm{p}<0.05)$. İşten ayrılma niyeti ile Covid-19 korkusunun arasında pozitif yönde anlamlı bir ilişki bulunmaktadır $(\beta=.25)$. İşten ayrılma niyeti ile iş performansı arasında negatif yönde anlamlı bir ilişki bulunmaktadır $(\beta=-.21)$.

Bağımsız değişkenin bağımlı değişken üzerinde etkisi anlamlı iken, bu etkide aracı rolü olup olmadığına bakılmıştır. Elde edilen modelin sonuçlara göre \%95 güven aralığındaki değerlerin $0^{\prime} 1$ içerdiği için modelde aracı rolünün olmadığını göstermektedir $(-0.007,0.014)$. 
Covid-19 Korkusu, Kişilik Özellikleri Ve İş Performansı Arasındaki Yordayıcı İlişkilere Yönelik Model

Dışadönüklük, covid-19 korkusu, iş performansı arasındaki yordayıcı ilişkilere yönelik model: Dışadönüklük, Covid-19 korkusu, iş performansı arasındaki yordayıcı ilişkilere yönelik kurulan modelin uyum indeksi değerleri Tablo 8'de sunulmuştur. Tablo 8'de yer alan uyum değerleri incelendiğinde X2/sd, RMSEA, SRMR, NFI, CFI, AGFI, TLI ve GFI değerlerinin kabul edilebilir uyum değerlerine karşılık geldiği anlaşılmaktadır. Dolayısıyla bu değerler doğrultusunda yapısal eşitlik modelinin genel olarak, istenen düzeyde uyum değerlerine sahip olduğu anlaşılmaktadır.

Tablo 8. Dışadönüklük kişilik boyutu yapısal eşitlik modeli uyum değerlerine ilişkin istatistikler

\begin{tabular}{lllllllll}
\hline Ölçüm & $(\mathbf{X} 2 / \mathrm{sd})$ & RMSEA & SRMR & NFI & CFI & GFI & AGFI & TLI \\
\hline $\begin{array}{l}\text { Modelin Uyum } \\
\text { İndeksi Değerleri }\end{array}$ & 4,08 & 0,08 & 0,06 & 0,87 & 0,9 & 0,89 & 0,86 & 0,89 \\
\hline
\end{tabular}

Test edilen ilk modelde, dışadönüklük kişilik özelliğinin iş performansı üzerindeki etkisinde korku değişkeninin aracılık rolü olup olmadığını test etmek amaciyla oluşturulan model Şekil 4'te gösterilmiştir.

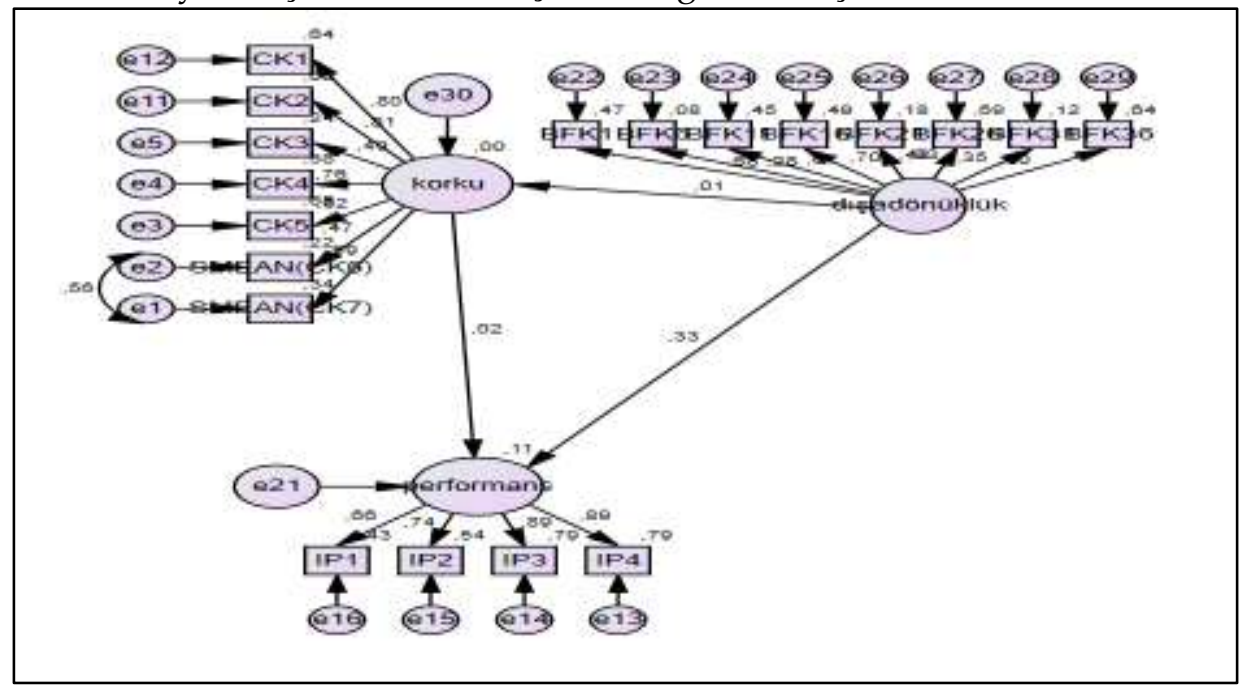

Şekil 4. Dışadönüklük Kişilik Boyutu Yapısal Eşitlik Modeline İlişkin Yol Analizi 
Tablo 9. Dişadönüklük kişilik boyutu yapısal eşitlik modeli

\begin{tabular}{llllll}
\hline Yol & Katsayı & Std. Katsayı & Std. Hata & $\mathbf{t}$ & $\mathbf{p}$ \\
\hline Covid-19 korkusu $\leftarrow$ Dışadönüklük & .01 & .01 & 0.04 & .23 & .81 \\
\hline İș performansı $\leftarrow$ Dişadönüklük & .45 & .33 & .07 & 6.79 & ${ }^{* * *}$ \\
\hline İş performansı $\leftarrow$ Covid-19 korkusu & .03 & .02 & .07 & .41 & .68 \\
\hline
\end{tabular}

*Tüm değerlerin anlamlılık düzeyi $\mathrm{p}<.05$ olarak hesaplanmıştır.

Oluşturulmuş olan modelde aracılık rolüne bakmadan önce bağımsız değişkenin bağımlı değişken üzerinde etkisinin olup olmadığı incelenmiştir. Dışadönüklük kişilik özelliğinin Covid-19 korkusu üzerinde anlamlı bir yordayıcılığ özelliğinin, iş performansını anlamlı bir şekilde yordadığı görülmektedir $(t=6.79, p<0.05)$. Dışadönüklük kişilik özelliği ile iş performansı arasında pozitif yönde anlamlı bir ilişki bulunmaktadır $(\beta=.33)$. Modelde Covid-19 korkusunun iş performansı üzerinde anlamlı bir etkisinin olmadığı görülmekte$\operatorname{dir}(t=., p>0.5)$. Bağımsız değişkenin bağımlı değişken üzerinde etkisi anlamlı iken, bu etkide aracı rolü olup olmadığına bakılmıştır. Elde edilen modelin sonuçlara göre \%95 güven aralığındaki değerlerin $0^{\prime} 1$ içermesi modelde aracı rolünün olmadığını göstermektedir $(-0.006,0.005)$.

Sorumluluk, covid-19 korkusu, iş performansı arasındaki yordayıcı ilişkilere yönelik model: Sorumluluk, Covid-19 korkusu, iş performansı arasındaki yordayıcı ilişkilere yönelik kurulan modelin uyum indeksi değerleri Tablo $10^{\prime}$ da sunulmuştur. Tablo $10^{\prime}$ da yer alan uyum değerleri incelendiğinde X2/sd, RMSEA, SRMR, NFI, CFI, AGFI, TLI ve GFI değerlerinin kabul edilebilir uyum değerlerine karşılık geldiği anlaşılmaktadır. Dolayısıyla bu değerler doğrultusunda yapısal eşitlik modelinin genel olarak, istenen düzeyde uyum değerlerine sahip olduğu anlaşılmaktadır.

Tablo 10. Sorumluluk kişilik boyutu yapısal eşitlik modeli uyum değerlerine ilişkin istatistikler

\begin{tabular}{lllllllll}
\hline Ölçüm & $\mathbf{( X 2 / s d )}$ & RMSEA & SRMR & NFI & CFI & GFI & AGFI & TLI \\
\hline $\begin{array}{l}\text { Modelin Uyum } \\
\text { İndeksi Değerleri }\end{array}$ & 3,53 & 0,07 & 0,06 & 0,87 & 0,9 & 0,9 & 0,87 & 0,89 \\
\hline
\end{tabular}

Test edilen ilk modelde, sorumluluk kişilik özelliğinin iş performansı üzerindeki etkisinde korku değişkeninin aracılık rolü olup olmadığını test etmek amaciyla oluşturulan model Şekil 5'te gösterilmiştir. 


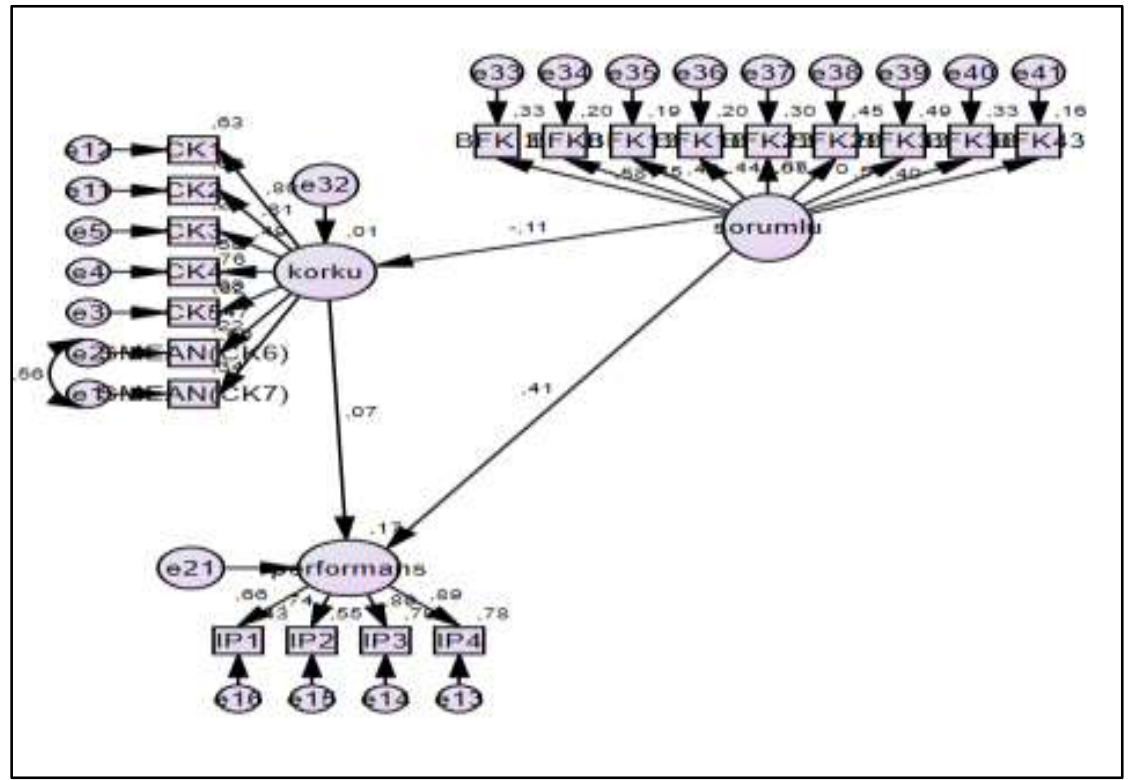

Şekil 5. Sorumluluk Kişilik Boyutu Yapısal Eşitlik Modeline İlişkin Yol Analizi

Tablo 11. Sorumluluk kişilik boyutu yapısal eşitlik modeli

\begin{tabular}{lllllll}
\hline Yol & Katsayı & $\begin{array}{l}\text { Std. } \\
\text { sayı }\end{array}$ & Kat- & Std. Hata & $\mathbf{t}$ & $\mathbf{p}$ \\
\hline Covid-19 korkusu $\leftarrow$ Sorumluluk & -.13 & -.11 & .06 & -2.16 & .03 \\
\hline İș performansı $\leftarrow$ Sorumluluk & .75 & .414 & .10 & 7.42 & $* * *$ \\
\hline İş performansı $\leftarrow$ Covid-19 korkusu & .11 & .07 & .07 & 1.50 & .13 \\
\hline
\end{tabular}

${ }^{*}$ Tüm değerlerin anlamlılık düzeyi $\mathrm{p}<.05$ olarak hesaplanmıştır.

Oluşturulmuş olan modelde aracılık rolüne bakmadan önce bağımsız değişkenin bağımlı değişken üzerinde etkisinin olup olmadığ 1 incelenmiştir. Sorumluluk kişilik özelliğinin Covid-19 korkusunu anlamlı bir şekilde yordadığı bulunmuştur ( $\mathrm{t}=-2.16, \mathrm{p}<0.05)$. Sorumluluk kişilik özelliği ile Covid-19 korkusu arasında negatif yönde anlamlı bir ilişki bulunmaktadır $(\beta=-.11)$. Modelde sorumluluk kişilik özelliğinin, iş performansını anlamlı bir şekilde yordadığı görülmektedir $(\mathrm{t}=7.42, \mathrm{p}<0.05)$. Sorumluluk kişilik özelliği ile iş performansı arasında pozitif yönde anlamlı bir ilişki bulunmaktadır ( $\beta=.41)$. Modelde Covid-19 korkusunun iş performansı üzerinde anlamlı bir etkisinin olmadığı görülmektedir ( $\mathrm{t}=1.50, \mathrm{p}>0.05)$. Bağımsız değişkenin bağımlı değişken üzerinde etkisi anlamlı iken, bu etkide aracı rolü olup olmadığına bakılmıştır. 
Elde edilen modelin sonuçlara göre \%95 güven aralığındaki değerlerin $0^{\prime} 1$ içermesi modelde aracı rolünün olmadığını göstermektedir $(-0.026,0.002)$.

Deneyime açıklık, covid-19 korkusu, iş performansı arasındaki yordayıcı ilişkilere yönelik model: Deneyime açıklık, Covid-19 korkusu, iş performansı arasındaki yordayıcı ilişkilere yönelik kurulan modelin uyum indeksi değerleri Tablo 12' de sunulmuştur. Tablo 12' de yer alan uyum değerleri incelendiğinde X2/sd, RMSEA, SRMR, NFI, CFI, AGFI, TLI ve GFI değerlerinin kabul edilebilir uyum değerlerine karşılık geldiği anlaşılmaktadır. Dolayısıyla bu değerler doğrultusunda yapısal eşitlik modelinin genel olarak, istenen düzeyde uyum değerlerine sahip olduğu anlaşılmaktadır.

Tablo 12. Deneyime açıklık kişilik boyutu yapısal eşitlik modeli uyum değerlerine ilişkin istatistikler

\begin{tabular}{lllllllll}
\hline Ölçüm & $\mathbf{( X 2 / s d )}$ & RMSEA & SRMR & NFI & CFI & GFI & AGFI & TLI \\
\hline $\begin{array}{l}\text { Modelin Uyum } \\
\text { İndeksi Değerleri }\end{array}$ & 3,86 & 0,07 & 0,06 & 0,87 & 0,9 & 0,89 & 0,86 & 0,88 \\
\hline
\end{tabular}

Test edilen ilk modelde, deneyime açıklık kişilik özelliğinin iş performansı üzerindeki etkisinde korku değişkeninin araclık rolü olup olmadığını test etmek amaciyla oluşturulan model Şekil 6' da gösterilmiştir.

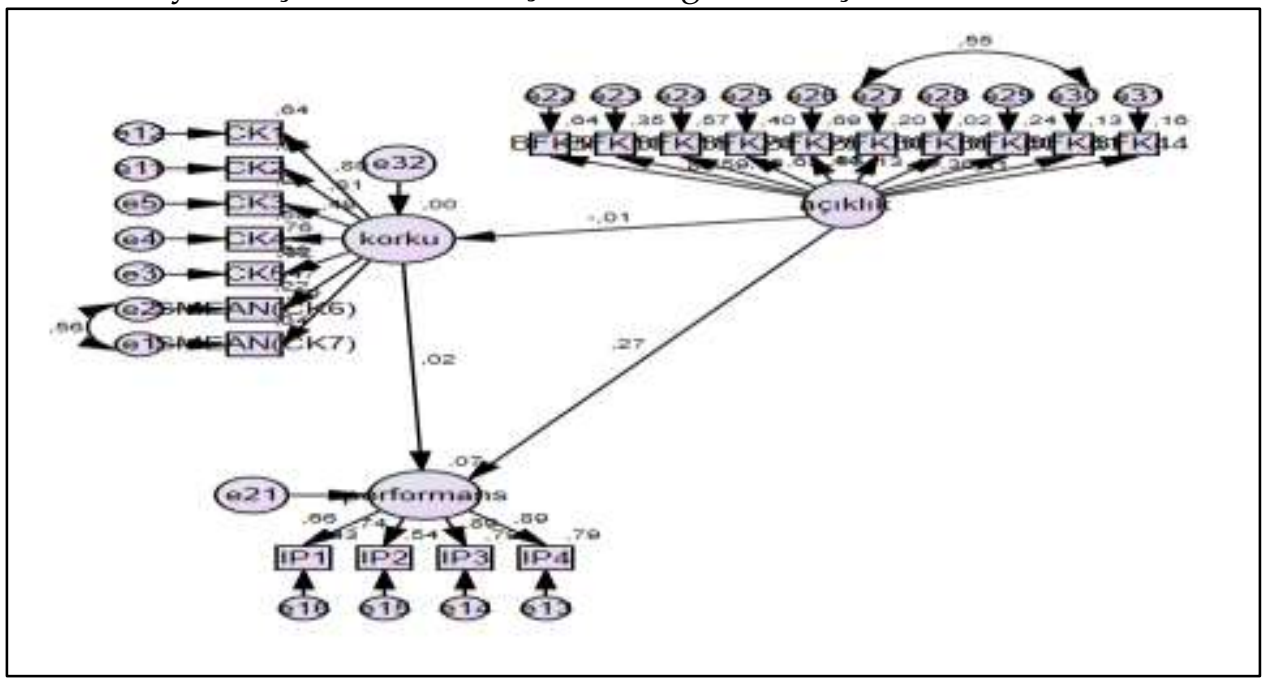

Şekil 6. Deneyime Açıklık Kişilik Boyutu Yapısal Eşitlik Modeline İlişkin Yol Analizi 
Tablo 13. Deneyime açıklık kişilik boyutu yapısal eşitlik modeli

\begin{tabular}{llllll}
\hline Yol & Katsayı & Std. Katsayı & Std. Hata & $\mathbf{t}$ & $\mathbf{p}$ \\
\hline Covid-19 korkusu $\leftarrow$ Deneyime açıklk & -.00 & -.00 & .04 & -.11 & .90 \\
\hline İş performansı $\leftarrow$ Deneyime açıklık & .30 & .27 & .05 & 5.61 & $* * *$ \\
\hline İş performansı $\leftarrow$ Covid-19 korkusu & .04 & .02 & .07 & .513 & .61 \\
\hline
\end{tabular}

*Tüm değerlerin anlamlılık düzeyi $\mathrm{p}<.01$ olarak hesaplanmıştır.

Oluşturulmuş olan modelde aracılık rolüne bakmadan önce bağımsız değişkenin bağıml değişken üzerinde etkisinin olup olmadığı incelenmiştir. Deneyime açıklık kişilik özelliğinin Covid-19 korkusu üzerinde anlamlı bir yordayıcılığı olmadığı bulunmuştur $(t=-.11, \mathrm{p}>0.05)$. Modelde deneyime açıklık kişilik özelliğinin, iş performansını anlamlı bir şekilde yordadığı görülmektedir $(t=5.13, p<0.05)$. Deneyime açıklık kişilik özelliği ile iş performansı arasında pozitif yönde anlamlı bir ilişki bulunmaktadır $(\beta=.27)$. Modelde Covid-19 korkusunun iş performansı üzerinde anlamlı bir etkisinin olmadığı görülmektedir ( $\mathrm{t}=0.51, \mathrm{p}>0.05)$. Bağımsız değişkenin bağımlı değişken üzerinde etkisi anlamlı iken, bu etkide aracı rolü olup olmadığına bakılmıştır. Elde edilen modelin sonuçlara göre \%95 güven aralığındaki değerlerin 0'1 içermesi modelde aracı rolünün olmadığını göstermektedir $(-0.007,0.005)$.

Uyumluluk, covid-19 korkusu, iş performansı ve işten ayrnlma niyeti arasındaki yordayıcı ilişkilere yönelik model

Uyumluluk, Covid-19 korkusu, iş performansı arasındaki yordayıcı ilişkilere yönelik kurulan modelin uyum indeksi değerleri Tablo 14'de sunulmuştur. Tablo 14'de yer alan uyum değerleri incelendiğinde X2/sd, RMSEA, SRMR, NFI, CFI, AGFI, TLI ve GFI değerlerinin kabul edilebilir uyum değerlerine karşılık geldiği anlaşılmaktadır. Dolayısıyla bu değerler doğrultusunda yapısal eşitlik modelinin genel olarak, istenen düzeyde uyum değerlerine sahip olduğu anlaşılmaktadır.

Tablo 14. Uyumluluk kişilik boyutu yapısal eşitlik modeli uyum değerlerine ilişkin istatistikler

\begin{tabular}{lllllllll}
\hline Ölçüm & $\mathbf{( X 2 / s d )}$ & RMSEA & SRMR & NFI & CFI & GFI & AGFI & TLI \\
\hline $\begin{array}{l}\text { Modelin Uyum } \\
\text { İndeksi Değerleri }\end{array}$ & 3,64 & 0,07 & 0,06 & 0,85 & 0,89 & 0,9 & 0,87 & 0,87 \\
\hline
\end{tabular}


Test edilen ilk modelde, uyumluluk kişilik özelliğinin iş performansı üzerindeki etkisinde korku değişkeninin aracılık rolü olup olmadığını test etmek amaciyla oluşturulan model Şekil 7'de gösterilmiştir.

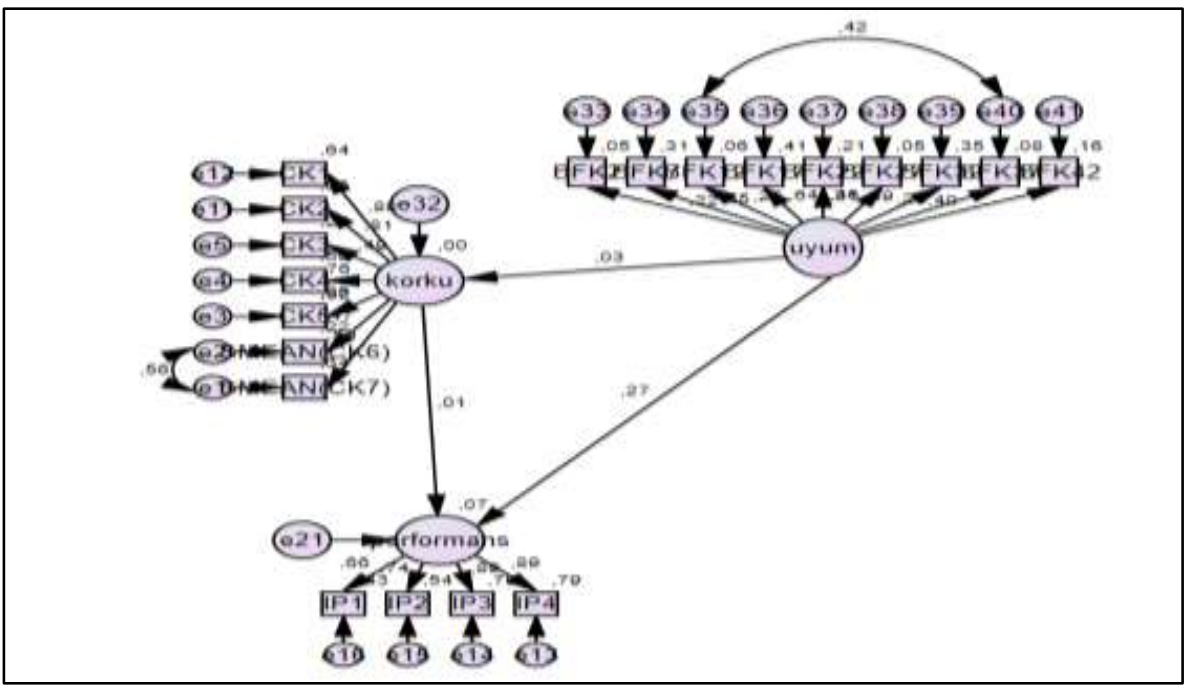

Şekil 7. Uyumluluk Kişilik Boyutu Yapısal Eşitlik Modeline İlişkin Yol Analizi

Tablo 15. Uyumluluk kişilik boyutu yapısal eșitlik modeli

\begin{tabular}{llllll}
\hline Yol & Katsayı & Std. Katsayı & Std. Hata & $\mathbf{t}$ & $\mathbf{p}$ \\
\hline Covid-19 korkusu $\leftarrow$ Uyumluluk & .08 & .03 & .14 & .57 & .57 \\
\hline İş performansı $\leftarrow$ Uyumluluk & .96 & .25 & .29 & 3.22 &.$* * *$ \\
\hline İş performansı $\leftarrow$ Covid-19 korkusu & .01 & .02 & .07 & 0.30 & .767 \\
\hline
\end{tabular}

*Tüm değerlerin anlamllık düzeyi $\mathrm{p}<.05$ olarak hesaplanmıştır.

Oluşturulmuş olan modelde aracılık rolüne bakmadan önce bağımsız değişkenin bağımlı değişken üzerinde etkisinin olup olmadığı incelenmiştir. Uyumluluk kişilik özelliğinin iş performansı ( $\mathrm{t}=3.22$, p $>0.05)$ üzerinde anlamlı bir etkisinin olduğu görülmektedir. Uyumluluk kişilik özelliğinin Covid-19 korkusu $(t=.57, \mathrm{p}>0.05$ üzerinde anlamlı bir etkisinin olmadığ görülmektedir. Modelde ayrıca Covid-19 korkusunun iş performansı anlamlı bir etkisinin olmadığı görülmektedir ( $\mathrm{t}=1.26)$.

Bağımsız değişkenin bağımlı değişken üzerinde etkisi anlamlı iken, bu etkide aracı rolü olup olmadığına bakılmıştır. Elde edilen modelin sonuçlara göre \%95 güven aralığındaki değerlerin $0^{\prime} 1$ içermesi modelde aracı rolünün olmadığını göstermektedir $(-0.007,0.006)$. 
Nevrotiklik, covid-19 korkusu, iş performansı arasındaki yordayıcı ilişkilere yönelik model: Nevrotiklik, Covid-19 korkusu, iş performansı arasındaki yordayıcı ilişkilere yönelik kurulan modelin uyum indeksi değerleri Tablo 16' da sunulmuştur. Tablo 16 'da yer alan uyum değerleri incelendiğinde $\mathrm{X} 2 / \mathrm{sd}$, RMSEA, SRMR, NFI, CFI, AGFI, TLI ve GFI değerlerinin kabul edilebilir uyum değerlerine karşılık geldiği anlaşılmaktadır. Dolayısıyla bu değerler doğrultusunda yapısal eşitlik modelinin genel olarak, istenen düzeyde uyum değerlerine sahip olduğu anlaşılmaktadır.

Tablo 16. Neorotiklik kişilik boyutu yapısal eşitlik modeli uyum değerlerine ilişkin istatistikler

\begin{tabular}{lllllllll}
\hline Ölçü̈m & $\mathbf{( X 2 / s d )}$ & RMSEA & SRMR & NFI & CFI & GFI & AGFI & TLI \\
\hline $\begin{array}{l}\text { Modelin Uyum } \\
\text { İndeksi Değerleri }\end{array}$ & 4,11 & 0,07 & 0,06 & 0,87 & 0,89 & 0,89 & 0,86 & 0,88 \\
\hline
\end{tabular}

Test edilen ilk modelde, nevrotiklik kişilik özelliğinin iş performansı üzerindeki etkisinde korku değişkeninin aracılık rolü olup olmadığını test etmek amacıyla oluşturulan model Şekil 8' de gösterilmiştir.

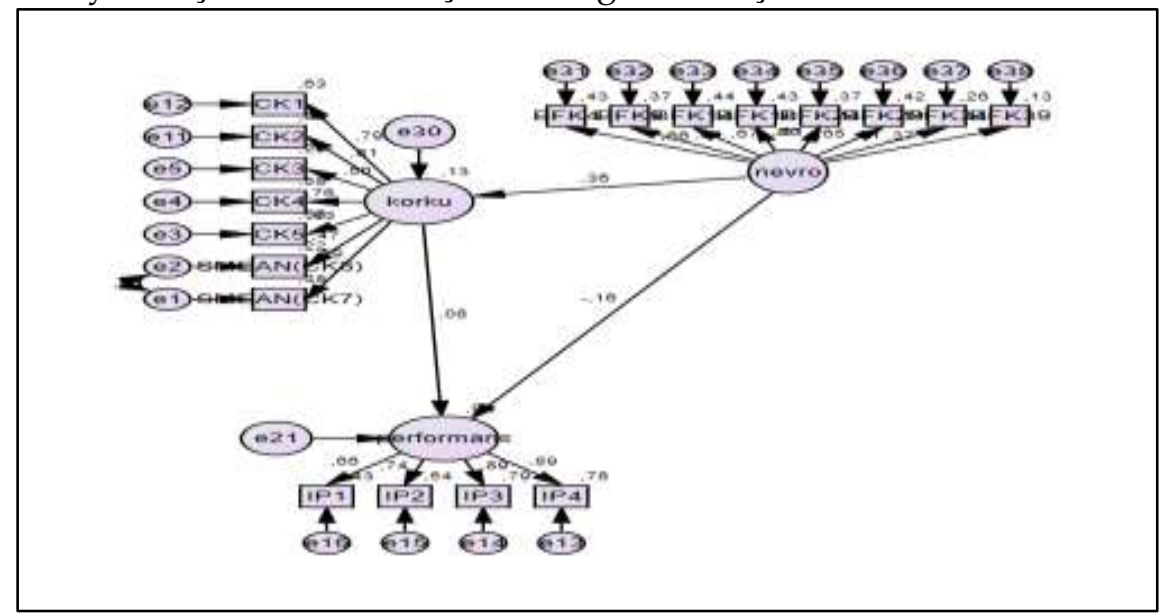

Şekil 8. Nevrotiklik Kişilik Boyutu Yapısal Eşitlik Modeline İlişkin Yol Analizi

Tablo 17. Nevrotiklik kişilik boyutu yapısal eşitlik modeli

\begin{tabular}{llllll}
\hline Yol & Katsayı & Std. Katsayı & Std. Hata & $\mathbf{t}$ & $\mathbf{p}$ \\
\hline Covid-19 korkusu $\leftarrow$ Nevrotiklik & .28 & .36 & .04 & 6.50 & $* * *$ \\
\hline İș performansı $\leftarrow$ Nevrotiklik & .19 & -.16 & .06 & -2.99 & .003 \\
\hline İş performansı $\leftarrow$ Covid-19 korkusu & .13 & .08 & .08 & 1.58 & .115 \\
\hline
\end{tabular}

*Tüm değerlerin anlamlılık düzeyi $\mathrm{p}<.05$ olarak hesaplanmıştır. 
Oluşturulmuş olan modelde aracılık rolüne bakmadan önce bağımsız değişkenin bağımlı değişken üzerinde etkisinin olup olmadığı incelenmiştir. nevrotiklik kişilik özelliğinin Covid-19 korkusunu anlamlı bir şekilde yordadığ1 görülmektedir $(\mathrm{t}=6.50, \mathrm{p}<0.05)$. Nevrotiklik kişilik özelliği ile Covid-19 korkusu arasında pozitif yönde anlamlı bir ilişki bulunmaktadır $(\beta=.36)$. Modelde nevrotiklik kişilik özelliğinin ( $\mathrm{t}=2.99)$ iş performansı üzerinde anlamlı bir etkisinin olduğu ve Covid-19 korkusunun ( $\mathrm{t}=1.58)$ iş performansı üzerinde anlamlı bir etkisinin olmadığ 1 görülmektedir.

Bağımsız değişkenin bağımlı değişken üzerinde etkisi anlamlı iken, bu etkide aracı rolü olup olmadığına bakılmıştır. Elde edilen modelin sonuçlara göre \%95 güven aralığındaki değerlerin $0^{\prime} 1$ içermesi modelde aracı rolünün olmadığını göstermektedir $(-0.007,0.070)$.

\section{Tartışma ve Sonuç}

Çalışmada Covid-19 korkusunun iş performansı üzerinde anlamlı bir etkisi bulunmazken, Covid-19 korkusunun ve iş performansının, işten ayrılma niyetini yordayan önemli değişkenler olduğu ortaya koyulmuştur. Buna göre, çalışanların iş performansının düşük olması, işten ayrılma niyetlerini yükselten önemli bir faktördür. Literatür incelendiğinde, iş performansı ve işten ayrılma niyeti arasında olumsuz bir ilişki olduğunu destekleyen çalışmalara rastlanmaktadır (Beğenirbaş ve Çalışkan, 2014; Özdemir ve Yayll, 2014). Ayrıca iş performansı ve işten ayrılma arasında çift yönlü bir ilişki olduğu da belirtilmektedir (Kanbur, 2018). Diğer bir deyişle işten ayrılma niyeti, iş performansının önemli bir belirleyicisi olabileceği gibi, iş performansı da işten ayrılma niyetini etkileyebilir (Tekingündüz, Top ve Seçkin, 2015). İşten ayrılma niyeti, bireyin çalıştığı kuruluştan ayrılma konusunda bilinçli ve kasıtlı olarak istekli olması; işi bırakma düşüncesi ve alternatif iş arama niyeti üzerine sürekli tartışmasıdır (Tett ve Meyer, 1993). Iş̧ten ayrılma niyeti, çalışanın işten ayrılacağının en önemli göstergesi olarak kabul edilmektedir (Griffeth, Hom ve Gaertner, 2000). İşten ayrılma düşüncesinde olan çalışanlar, işle ilgili durumlara yeterince konsantre olamamakta ve verimlilikleri düşmektedir. Bunlar ayrıca iş performansını düşüren etkenler olarak karşımıza çıkmaktadır (Çekmecelioğlu, 2014). 
Çalışmada işten ayrılma niyetini etkileyen bir diğer önemli değişkenin Covid-19 korkusu olduğu ortaya koyulmuştur. Buna göre, Covid-19 korkusunun yüksek olması, işten ayrılma niyetini etkileyen önemli bir belirleyicidir. Bu sonuç, literatürde yer alan araştırma sonuçlarıyla paralellik göstermektedir. Khattak, Saeed, Rehman ve Fayaz (2020) tarafından yapılan çalışmada, Covid-19 korkusunun işten ayrılma niyetini artıran önemli bir etkiye sahip olduğu ve bu ilişkide liderlik desteğinin 1 lımlı bir rol oynadığı bulunmuştur. Bir başka çalışmada ise Covid-19 korkusu yükseldikçe iş tatminin düştüğü, psikolojik sıkıntı ve işten ayrılma niyetinin ise arttı̆ı ortaya koyulmuştur (Labrague ve De los Santos, 2020). Covid-19 sürecinde çalışanların işten ayrılma niyetini etkileyen en önemli değişkenler işe bağlllık, istek ve odaklanmasının düşük olmasıdır. Ayrıca işin devamlılığı konusunda kayg1ları içeren iş güvensizliği de işe bağlllığı etkileyen önemli bir faktör olarak belirtilmiştir (Jung, Jung ve Yoon, 2020).

Covid-19 salgınının ortaya çıkardığı değişiklikler ve bu değişikliklerin yaşam üzerinde yarattı̆̆ sonuçlardan her birey aynı şekilde etkilenmemektedir. Kişilik gibi bireysel farklılıklar, Covid-19 salgını sürecinde koruyucu davranışların benimsenmesi, psikolojik ve fizyolojik iyi olma hali gibi birçok etken üzerinde etkilidir. Ayrıca bu süreçte çalışma yaşamında gerçekleşen değişimler ve sürecin öngörülemezliği, çalışanların iş performansını da etkilemiştir. Araştırmada nevrotiklik kişilik özelliğinin, Covid-19 korkusunu artıran, iş performansını ise azaltan önemli bir etken olduğu; sorumluluk kişilik özelliğinin ise tam tersi Covid-19 korkusunu azaltan ve iş performansını artıran önemli bir belirleyici olduğu bulunmuştur. Ayrıca deneyime açıklık, d1şadönüklük ve uyumluluk kişilik özelliklerinin, iş performansına katkıda bulunan önemli beş faktör kişilik özellikleri olduğu ortaya koyulmuştur.

Nevrotiklik, kaygı, kızgınlık, düşmanlık, depresyon, dürtüsellik gibi olumsuz duygusal durumları deneyimleme eğilimi olarak tanımlanmaktadır (Costa ve McCrae, 1995). Nevrotik kişilik özelliğine sahip bireyler, dünyayı tehdit edici olarak algılar, hızlı bir şekilde üzülebilir ve ani duygudurum değişimleri yaşayabilirler. Dolayısıyla nevrotiklik, duygusal stres yaşamaya yatkın bir kişilik yapısıdır, bu da Covid-19 salgın sürecinde bireyleri psikolojik sıkıntılara karşı daha savunmasız bir hale getirmektedir (Taylor, 2019). Dünya çapında bir salgın krizinin yaşandığı bu süreçte farklı ülkelerde yürütülen çalışmalar, nevrotiklik düzeyi yüksek bireylerin, Covid-19 ile ilgili bilgilere daha fazla dikkat ettikleri ve salgının sonuçları hakkında daha fazla 
endişelendiklerini (Kroencke vd, 2020), küresel ekonomik kriz beklentisi içinde olduklarını (Öngel, Tatlı ve Bozkurt, 2020), salgına ilişkin daha büyük bir tehdit algıladıklarını (Garbe vd, 2020), salgından kaynaklı depresyon ve yaygın anksiyete düzeylerinin yüksek olduğunu (Lee ve Crunk, 2020) göstermektedir. Dolayısıyla nevrotiklik kişilik özelliği endişeli ve stresli yanlarıyla Covid-19 korkusunu artıran önemli bir faktör olarak değerlendirilmektedir.

Ozer ve Benet- Martinez (2006), olumsuz duygulara duyarlılıkla karakterize olan nevrotikliğin, bir bireyin işte ne kadar iyi olduğu konusunda önemli bir belirleyici olabileceğini ifade etmektedir. Nevrotik kişiliğin, duygusal olarak istikrarsız özellikler göstermesi, çalışanların motivasyonunu olumsuz etkileyerek, iş performansını düşürebilir (Barrick, Stewart ve Piotrowski, 2002). Örneğin Törnroos, Jokela ve Hakulinen (2019) tarafından yapılan çalışmada bireylerin nevrotiklik kişilik özelliğine sahip olma düzeyleri düştükçe, iş tatminin yükseldiği bulunmuştur. Dolayısıyla çalışmada elde edilen sonuç, alanyazındaki çalışmalarla paralellik göstermektedir. Buna göre, nevrotik kişilik özelliğine sahip bireylerin duygusal olarak stresli yaşam tarzları sebebiyle, iş performanslarının düşük olması muhtemeldir.

Sorumluluk, bir diğer adıyla özdisiplin kişilik özelliği çalışkanlık, düzenli ve planlı olma, azimli olma gibi özelliklerinden dolayı çalışma yaşamı ile sıklıkla ilişkilendirilen özelliklerden biridir. Alanyazında sorumluluk kişilik özelliği, iş performansı ile ilişkisi en yüksek olan bireysel faktörlerden biri olarak değerlendirilmektedir (He, Donnellan ve Mendoza, 2019). Buna göre, bir bireyin sorumluluk kişilik özelliğine sahip olması onun iş performansına katkıda bulunmaktadır (Yelboğa, 2006). Sorumluluk kişilik özelliğinin ayrıca iş yaşamında önemli faktörlerden biri olan örgütsel yaratıcılık ile ilişkili olduğu görülmektedir (Yılmaz, 2019). Bu çerçevede alanyazınla tutarlı sonuçlar elde edildiği görülmektedir. Sorumluluk kişilik özelliğine sahip bireyler, disiplinli, görev bilinci yüksek, başarı yönelimli ve sorumluluk sahibi kişilerdir (Şahin, 2017). Bu özellikler çalışma yaşamı için aranan özellikler olup, bu kişilik özelliğini taşıyan çalışanların iş hedeflerine ulaşmaları, görevlerini zamanında tamamlamaları, belirlenen standartlara ulaşmaları beklenen bir durumdur. Dolayısıyla sorumluluk kişilik özelliği, iş performansı ile yakından ilişkili olarak değerlendirilmektedir.

Çalışmada aynı zamanda sorumluluk kişilik özelliğinin, Covid-19 korkusu için önemli bir faktör olduğu görülmektedir. Bir diğer deyişle, bireylerin 
sorumluluk kişilik özelliğine sahip olma düzeyleri arttıkça Covid-19 korkuları azalmaktadır. Sorumluluk kişilik özelliğine sahip bireylerin, bu süreçte daha sık alışverişe ve tuvalet kâğıdı gibi ürünleri stok yapmaya yöneldiği (Garbe vd, 2020), sosyal mesafe ve el yıkama tedbirlerine daha bağlı olduğu (Carvalho vd, 2020) bulunmuştur. İleri görüşlü ve düzenli bir yaşam tarzı olan sorumluluk kişilik özelliğine sahip bireylerin, belirsiz olan Covid-19 sürecinde stok yaparak zor durumlara karşı bir tedbir almak istemesi beklenen bir durumdur. Ayrıca sorumluluk bilinci yüksek olan bu kişilerin virüsün yayılımını azaltmaya yönelik tedbirlere uymayı daha kolay kabullenmesi ve bu tedbirleri benimsemesi daha olasıdır. Dolayısıyla tüm bu özellikler, sorumluluk kişilik özelliğinin kavramsallaştırılmasıyla tutarlılık göstermekte ve çalı̧̧mada elde edilen sonucu desteklemektedir.

İş performansı üzerinde etkili olan bir diğer kişilik özelliği dışadönüklüktür. Dışadönüklük sosyallik ve girişkenlik başta olmak üzere, olumlu duygular, samimiyet, konuşkanlık, insanlarla ilişki içerisinde kalma isteği gibi özellikleri kapsar (Costa ve McCrae, 1995). Dışadönük olmak, çalışma yaşamında özellikle etkileşim ve iş birliği gerektiren işlerde yüksek performansla ilişkili olarak görülmektedir. Olumlu duyguların ön planda olması, işle ilgili öz yeterlik algısını olumlu etkilemekte ve kişisel başarı üzerinde güçlü bir etki yaratmaktadır (Swider ve Zimmerman, 2010). Dışadönüklüğün, beklenti temelli iş memnuniyeti ve performans memnuniyeti olmak üzere iş memnuniyetinin her iki boyutuyla da olumlu ilişki içerisinde olduğu bulunmuştur (Avery, Smillie ve Fife-Schaw, 2015). Yapılan bir çalışmada, dışadönük kişiliğe sahip ve evden çalışan kişilerin, tükenmişlik semptomları yaşamaya daha yatkın oldukları ortaya koyulmuştur (Meymandpour ve Bagheri, 2017). Bu çalışmada bireylerin dışadönük kişilik özelliğine sahip olmalarının, onların iş performansını artıran bir faktör olduğu görülmüştür. Covid-19 salgınının normalleşme sürecinde yürütülen bu çalışmada, birçok çalışanın uzaktan çalışma şeklinden aktif çalışmaya geçtiği, bunun da dışadönük kişilerin sosyallik ihtiyaçlarını karşılamasını sağladığı ve iş performanslarına olumlu bir katkıda bulunduğu söylenebilir.

Çalışmada, deneyime açılık ve uyumluluk kişilik özelliklerinin de iş performansı üzerinde olumlu bir etkiye sahip olduğu görülmektedir. Deneyime açık kişilik özelliğine sahip bireylerin temel özellikleri aktif bir hayal gücü, estetik duyarlılık, içsel duygulara dikkat, çeşitliliği tercih etme eğilimi ve entelektüel meraktır. Bu özelliklerin birçoğu yaratıcılığı teşvik etmekte, bu da iş 
performansını yükselten bir etken olarak değerlendirilebilmektedir (Rothmann ve Coetzer, 2003). Ayrıca Gürkaynak (2017) tarafından yapılan çalışmada, deneyime açıklık kişilik özelliğe ile kurum kurallarına uyma, kaliteli iş üretimi, görevleri zamanında tamamlama ve iş performansı arasında ilişki olduğu bulunmuştur. Uyumluluk kişilik özelliği de çalışma yaşamı ile ilişkisi incelenen bir değişken olup, fedakârlık, başkalarına yardım etme isteği, işbirlikçilik, yumuşak başlılık gibi özelliklerle ön plana çıkmaktadır. Uyumluluk kişilik özelliğinin yönetim performansına katkıda bulunduğu (Rothmann ve Coetzer, 2003), yüksek iş tatmini (Törnroos vd, 2019) ve iş performansı (Gürkaynak, 2017) ile ilişkili olduğu ortaya koyulmuştur. Dolayısıyla çalışmada elde edilen sonuçların, alanyazınla tutarlılık gösterdiği söylenebilir.

Bu araştırmada Covid-19 korkusu, kişilik, iş performansı ve işten ayrılma niyeti arasındaki yordayıcı ilişkileri ortaya koymak amaçlanmıştır. Çalışmanın sonucunda Covid-19 korkusunun ve iş performansının, işten ayrılma niyetini etkileyen önemli belirleyiciler olduğu bulunmuştur. Dolayısıyla mevcut araştırma, Covid-19 sürecinde çalışma yaşamı ile ilgili önemli sonuçlar ortaya koymaktadır. Covid-19 salgını, stresli ve endişeli bir yaşam süreci ortaya çıkarmıştır ve insanların Covid-19'dan korkması birçok yönden onları etkilemektedir. İş yerinin gerekli hijyen ve mesafe tedbirleri almaması, işin bulaş riski taşıması gibi durumlar çalışanların kendini iş yerinde güvende hissetmemesine yol açmakta; bu da işle ilgili durumların daha stresli olarak değerlendirilmesine zemin hazırlamaktadır. Ayrıca bu süreçte çalışanların kaygıları artarken motivasyonları düşmektedir. Işse ilişkin tüm bu durumlar çalışanların işten ayrılma niyetini güçlendiren kritik faktörlerdir. İşten ayrılma niyeti, işten ayrılmanın en önemli belirleyicisi olup, bu durum kuruluşlara önemli ölçüde bir maliyet ve zaman kaybı yaşatmaktadır. Kuruluşların nitelikli çalışan iş gücünü kaybetmesi, işe alma ve eğitim için gereken çabaları tekrar sarf etmek zorunda kalması işten ayrılmanın olumsuz etkilerinden bazılarıdır. Ayrıca çalışma sonucunda, düşük iş performansının işten ayrılma niyetini önemli ölçüde yükselttiği belirlenmiştir. İş performansı düşen çalışan işten ayrılma düşünceleri geliştirebilmekte bu da işten ayrılma niyetine yansımaktadır. Covid-19 sürecinde süreçte iş yerlerinin iş performansını korumak için güvenli bir çalışma ortamı yaratarak çalışanların Covid-19 korkusunu en aza indirmeleri önem taşımaktadır.

Çalışanların kişilik özellikleri incelendiğinde nevrotiklik kişilik özelliğinin Covid-19 korkusunu yükselttiği ve iş performansını düşürdüğü; sorumluluk 
kişilik özelliğinin ise tam tersi Covid-19 korkusunu azalttı̆̆ 1 ve iş performansinı yükselttiği bulunmuştur. Deneyime açılık, dişadönüklük ve uyumluluk kişilik özelliklerinin ise iş performansına anlamlı bir şekilde katkıda bulunduğu ancak Covid-19 korkusuna anlamlı bir etkileri olmadığı ortaya koyulmuştur.

Çalışmada kişilik özelliklerinin hem Covid-19 korkusu hem de iş performansı üzerinde belirleyici bir etkisi olduğu bulunmuştur. Kişilik ile çalışma yaşamı arasındaki ilişki endüstri ve örgüt psikolojisinde sıklıkla incelenmiştir. Bireylerin kendi kişisel özelliklerine uygun işlerde çalışmaları, onların çalışma yaşamlarının niteliğine katkıda bulunmaktadır. Örgütler açısından baktığımızda ise, bir pozisyonda o pozisyona uygun yetenek ve kişilik özelliklerine sahip bir çalışanın olması kuruluşu olumlu etkilemektedir. Aksi takdirde çalışanı pozisyona uygun hale getirmek için yorucu ve uzun bir süreç olabilmektedir. Tüm bu sebeplerden dolayı birçok kuruluş, işe alım sürecine titizlik ile yaklaşmakta, hatta bu noktada kişilik testlerinden yararlanılabilmektedir. Çalışanların kendi kişisel özelliklerine uygun işlerde çalışmaları, onların iş performansının yüksek olmasını sağlayan önemli bir etkendir. Çalışanların iş performansının yüksek olması ise, bir örgütün hedeflerine ulaşmasında önemli noktalardan biridir. Sonuç olarak kişilik özellikleri ile iş performansı arasındaki ilişkilerin belirlenmesi işe alım, seçim ve kariyer süreciyle doğrudan bağlantılı olarak görülmektedir. Dolayısıyla bu ilişkinin anlaşılması hem bireylere hem de örgütlere çalışma yaşamına katkıda bulunacak birçok ipucu vermektedir. 


\title{
EXTENDED ABSTRACT
}

\section{Analysis of the Relationships Between Fear of Covid-19, Personality Traits, Job Performance and Turnover Intention}

*

\author{
Saniyebengisu Büyükmumcu - Büşra Yiğitol \\ Konya Food and Agriculture University
}

Nowadays business life has been experiencing devastating changes and challenges due to Covid-19 (New Coronavirus) pandemic. In this period, flexible working systems have been adopted in many sectors. Afterwards some workplaces have started to work actively with the normalization period, where some others have adopted hybrid working systems. Despite the risk of transmission during the pandemic, employees working in specific sectors had to continue to work even harder. Especially the health sector and some companies operating in the manufacturing sector had to continue working in this process. With the normalization, taking measures in workplaces both institutionally and individually and following these measures come to the agenda. Despite the institutional or individual measures taken in the workplaces, concerns and fears of Covid-19 are expected to have a negative impact on the work performance of employees, and in some cases it seems likely that this fear threatens the continuity of the employee's work life. It also has impact on employees' attitude towards their jobs. In this regard, the purpose of this study is to determine the effect of fear and anxiety caused by Covid-19 on employees' job performance and turnover intention, by considering their personality traits.

A questionnaire survey was conducted in order to investigate the relationships between job performance, turnover intention, fear of Covid-19, and personality traits of employees. The data was collected from 547 working individuals during June and July 2020 when the workplaces have undergone a normalization period in Turkey. Random sampling method was used in sample selection in the survey. By eliminating missing and incorrect data, the total data of 542 were included in the analysis. Job Performance 
Scale, Employment Intention Scale, Covid-19 Fear Scale, Personal Information Form and Personality Scale were used to evaluate the data collected from employees. Then the data was analyzed by Structural Equation Model (SEM) analysis based on via Amos 21 software. The results of the study reveal that fear of Covid-19 does not have a significant effect on job performance. On the other hand, fear of Covid-19 and job performance are important variables that affect turnover intention. Accordingly, the low job performance of the employees is an important factor that increases their turnover intention. In the study, it was revealed that another important variable that affects the turnover intention is the fear of Covid-19. Results show that as the fear of Covid-19 increases, the turnover in-tention of employees also increases. The changes caused by the Covid-19 outbreak and the consequences of these changes on business life do not affect everyone in the same way. Individual differences such as personality traits are effective on many factors such as the adoption of protective behaviors and psychological and physiological well-being during the Covid- 19 outbreak. It can be stated that neurotic and responsible personality traits of employees increase the fear of Covid-19. Individuals with neurotic personality traits perceive the world as threatening. Therefore, neuroticism is a personality structure prone to experiencing emotional stress, which makes individuals more vulnerable to psychological distress during the Covid-19 epidemic process. Individuals with neurotic personality traits are likely to have low job performance due to emotionally stressful lifestyles. Responsibility personality trait seems to be an important factor for the fear of Covid-19. In other words, as level of responsibility personality trait of individuals increases, their fear of Covid19 decreases. The personality traits of openness to experience, extraversion and adaptability were found to contribute significantly to job performance. It was concluded that, these three traits of personality do not have a significant impact on Covid-19 fear of employees. The current study reveals important results for employees and managers to cope with changing working conditions due to Covid-19. In this study, a cross-sectional method, which does not allow precise inferences about variables, was used. Therefore, it is not possible to talk about a clear causality relationship between variables. Qualitative research methods can be included to examine relationships between variables in the future studies. It can be stated that it will be useful 
to examine the predictive relationships between different dynamics in terms of different parties in the future studies regarding Covid-19.

The study reveals important results for employees to cope with the changing work life due to Covid-19. As far as the authors know there is no study in literature which analyze job performance, turnover intention and personal traits of employees in the context of Covid-19. For this reason, this study is expected to contribute to the existing literature by providing valuable results in terms of both the subject and the time period examined.

\section{Kaynakça / References}

Avery, R. E., Smillie, L. D. ve Fife-Schaw, C. R. (2015). Employee achievement orientations and personality as predictors of job satisfaction facets. Personality and Individual Differences, 76, 56-61.

Barrick, M. R., Stewart, G. L. ve Piotrowski, M. (2002). Personality and job performance: Test of the mediating effects of motivation among sales representatives. Journal of Applied Psychology, 87(1), 43.

Beğenirbaş, M., ve Çalışkan, A. (2014). Duygusal emeğin iş performansı ve işten ayrılma niyetine etkisinde kişilerarası çarpıklı̆̆ın aracılık rolü. Business and Economics Research Journal, 5(2), 109-127.

Bhosale, J. (2020). (https://realtime.rediff.com/news/india/Prices-of-agricultural-commodities-drop-20-post-COVID19-outbreak/955078599584b749?src=interim_alsoreadimage).

Campbell, J. (1990). Modeling the performance prediction problem in industrial and organizational psychology. M. Dunnette \& L. Hough (Eds.), Handbook of industrial and organizational psychology içinde (s. 686-707). Palo Alto, CA: Consulting Psychologists Press.

Carvalho, L. D. F., Pianowski, G. ve Gonçalves, A. P. (2020). Personality differences and COVID-19: are extroversion and conscientiousness personality traits associated with engagement with containment measures?. Trends in Psychiatry and Psychotherapy, (AHEAD).

Costa Jr, P. T. ve McCrae, R. R. (1995). Domains and facets: Hierarchical personality assessment using the Revised NEO Personality Inventory. Journal of Personality Assessment, 64(1), 21-50.

Çekmecelioğlu, H. G. (2014). Göreve ve insana yönelik liderlik tarzlarının örgütsel bağlllık, iş performansı ve işten ayrılma niyeti üzerindeki etkileri. Kocaeli Üniversitesi Sosyal Bilimler Dergisi (KOSBED), 28, 21-34. 
Deloitte (2020). Yeni nesil teknolojilerin covıd-19 mücadelesindeki önemi. 17.05.2020 tarihinde https://www2.deloitte.com/tr/tr/pages/consulting/articles/yeni-nesil-teknolojilerin-covid-19-mucadelesindeki-onemi.html adresinden erişildi.

Garbe, L., Rau, R. ve Toppe, T. (2020). Influence of perceived threat of Covid-19 and HEXACO personality traits on toilet paper stockpiling. Plos One, 15(6), e0234232.

Gasparro, R., Scandurra, C., Maldonato, N. M., Dolce, P., Bochicchio, V., Valletta, A. ..., Marenzi, G. (2020). Perceived job insecurity and depressive symptoms among italian dentists: the moderating role of fear of COVID-19. International Journal of Environmental Research and Public Health, 17(15), 5338.

Griffeth, R. W., Hom, P. W. ve Gaertner, S. (2000). A meta-analysis of antecedents and correlates of employee turnover: Update, moderator tests, and research implications for the next millennium. Journal of Management, 26(3), 463-488.

Gürkaynak, B. (2017). Çalışan iş performansinın değerlendirilmesinde insan kaynakları yönetimi uygulamalarmm etkililiği ve kişilik özelliklerinin rolü üzerine bir araştırma. Yayınlanmamış Yüksek Lisans Tezi. Sosyal Bilimler Enstitüsü, Başkent Üniversitesi, Ankara.

Haktanır, A., Seki, T. ve Dilmaç, B. (2020). Adaptation and evaluation of Turkish version of the fear of COVID-19 scale. Death Studies, 1-9.

Haleem, A., Javaid, M., ve Vaishya, R. (2020). Effects of COVID 19 pandemic in daily life. Current Medicine Research and Practice.

He, Y., Donnellan, M. B. ve Mendoza, A. M. (2019). Five-factor personality domains and job performance: A second order meta-analysis. Journal of Research in Personality, 82, 103848.

ILO, (2020). COVID-19 pandemisi, dünya genelinde, çalışma süreleri ve kazançlarda yıkıı etki yaratıyor. 21.05.2020 tarihinde https:/www.ilo.org/ankara/areas-ofwork/covid-19/WCMS 740868/lang--tr/index.htm adresinden erişilmiştir.

ILO, (2020a). ILO gözlem 2nci baskl: COVID-19 ve çalışma yaşamı. https://www.ilo.org/wcmsp5/groups/public/---europe/---ro-geneva/--iloankara/documents/briefingnote/wcms 741784.pdf

ILO, (2020b). COVID-19 and the education sector. https://www.ilo.org/wcmsp5/groups/public/--ed dialogue/--sector/documents/briefingnote/wcms 742025.pdf adresinden erişilmiştir.

Irshad, M., Khattak, S. A., Hassan, M. M., Majeed, M. ve Bashir, S. (2020). How perceived threat of Covid-19 causes turnover intention among Pakistani nurses: A moderation and mediation analysis. International Journal of Mental Health Nursing. 
Jung, H. S., Jung, Y. S. ve Yoon, H. H. COVID-19: The effects of job insecurity on the job engagement and turnover intent of deluxe hotel employees and the moderating role of generational characteristics. International Journal of Hospitality Management, 92, 102703.

Kanbur, E. (2018). Havacilık sektöründe psikolojik güçlendirme, iş performansı ve işten ayrılma niyeti arasındaki ilişkilerin incelenmesi. Uluslararası Yönetim İktisat ve İsletme Dergisi, 14(1), 147-162.

Kaya. N. (2016). Mobbingin örgütte adalet algısı ve örgütsel bağhllı ilişkisi ile çalışanlarm iş performansına ve işten ayrilma niyetine etkisi. Yayımlanmamış Doktora Tezi. Beykent Üniversitesi, Ankara.

Khattak, S. R., Saeed, I., Rehman, S. U. ve Fayaz, M. (2020). Impact of fear of COVID19 pandemic on the mental health of nurses in pakistan. Journal of Loss and Trauma, 1-15.

Kroencke, L., Geukes, K., Utesch, T., Kuper, N. ve Back, M. (2020). Neuroticism and emotional risk during the Covid-19 pandemic. Journal of Research in Personality, in press

Labrague, L. J. ve De los Santos, J. (2020). Fear of Covid-19, psychological distress, work satisfaction and turnover intention among frontline nurses. Journal of Nursing Management.

Lee, S. A. ve Crunk, E. A. (2020). Fear and psychopathology during the COVID-19 crisis: neuroticism, hypochondriasis, reassurance-seeking, and coronaphobia as fear factors. OMEGA-Journal of Death and Dying, 0030222820949350.

Meymandpour, R. ve Bagheri, Z. (2017). A study of personality traits, viz., extraversion and introversion on telecommuters burnout. Telecom Business Review, 10(1), 1 .

Nicola, M., Alsafi, Z., Sohrabi, C., Kerwan, A., Al-Jabir, A., Iosifidis, C., ... , Agha, R. (2020). The socio-economic implications of the coronavirus pandemic (COVID-19): A review. International Journal of Surgery (London, England), 78, 185.

Ozer, D. J. ve Benet-Martinez, V. (2006). Personality and the prediction of consequential outcomes. Annu. Rev. Psychol., 57, 401-421.

Öngel, V., Tatl, H. S. ve Bozkurt, G. (2020). Küresel krizlerde kişilik özelliklerine göre sosyal medya algısı: COVID-19 örneği. Turkish Studies, 15, 4.

Özdemir, H. ve Yaylı, A. (2014). Çalışanın örgütsel bağlılığını, performansı ve işte ayrılma niyeti arasındaki ilişkinin belirlenmesine yönelik bir araştırma. Journal Of Recreation and Toursm Research, 1(1), 48-58. 
Rothmann, S. ve Coetzer, E. P. (2003). The big five personality dimensions and job performance. SA Journal of Industrial Psychology, 29(1), 68-74.

Sasaki, N., Kuroda, R., Tsuno, K. ve Kawakami, N. (2020). Workplace responses to COVID-19 associated with mental health and work performance of employees in Japan. Journal of Occupational Health, 62(1), e12134.

Schermelleh-Engel, K., Moosbrugger, H. ve Müller, H. (2003). Evaluating the fit of structural equation models: Tests of significance and descriptive goodnessof-fit measures. Methods of Psychological Research Online, 8(2), 23-74.

Sigler, T. H. ve Pearson, C. M. (2000). Creating an empowering culture: examining the relationship between organizational culture and perceptions of empowerment. Journal of Quality Management, 5(1), 27-52.

Simon, D., Kriston, L., Loh, A., Spies, C., Scheibler, F., Wills, C. ve Härter, M. (2010). Confirmatory factor analysis and recommendations for improvement of the Autonomy-Preference-Index (API). Health Expectations, 13(3), 234-243.

Sümer, N. ve Sümer, H.C. (2005). Beş faktör kişilik özellikleri ölçeği. Yayınlanmamış çalişma.

Swider, B. W. ve Zimmerman, R. D. (2010). Born to burnout: A meta-analytic path model of personality, job burnout, and work outcomes. Journal of Vocational behavior, 76(3), 487-506.

Şahin, E. S. (2017). Ayırıc özellik kuramı: G.Allport, R.Cattell, P.T. Costa \& R.R. McCrae. D. Gençtanırım-Kurt ve E. Çetinkaya-Yıldız (Ed.), Kişilik kuramları gerçek yaşamdan kişilik analizi örnekleriyle içinde (s. 480-525). Ankara: Pegem Akademi.

Tan, W., Hao, F., McIntyre, R. S., Jiang, L., Jiang, X., Zhang, L. ... , Zhang, Z. (2020). Is returning to work during the COVID-19 pandemic stressful? A study on immediate mental health status and psychoneuroimmunity prevention measures of Chinese workforce. Brain, Behavior, and Immunity.

Taylor, S. (2019). The psychology of pandemics: Preparing for the next global outbreak of infectious disease. Cambridge Scholars Publishing.

Tekingündüz, S., Top, M. ve Seçkin, M. (2015). İş tatmini, performans, iş stresi ve işten ayrılma niyeti arasındaki ilişkilerin incelenmesi: Hastane örneği. Verimlilik Dergisi, 4, 39-64.

Tett, R. P. ve Meyer, J. P. (1993). Job satisfaction, organizational commitment, turnover intention, and turnover: path analyses based on meta-analytic findings. Personnel Psychology, 46(2), 259-293. 
Törnroos, M., Jokela, M. ve Hakulinen, C. (2019). The relationship between personality and job satisfaction across occupations. Personality and Individual Differences, $145,82-88$.

Tuna, A. A. ve Çelen, O. (2020). İşletmelerin insan kaynakları yönetimi uygulamaları üzerinde COVID-19 pandemisinin etkileri. OPUS Uluslararası Toplum Araşturmalar Dergisi, 16(30), 2710-2759.

Kuru Güngör, Y. (2020). Sağllk personelinin covid-19 korkusu ile tükenmişliği arasındaki ilişkide aşırı iş yükü ve algılanan sosyal desteğin etkisinin yapısal eşitlik modeliyle belirlenmesi. EKEV Akademi Dergisi, 24(83), 241-262.

Yelboğa, A. (2006). Kişilik özellikleri ve iş performansı arasındaki ilişkinin incelenmesi. ISGUC The Journal of Industrial Relations and Human Resources, 8(2), 196217.

Yılmaz, F. (2019). Hangi kişilik özelliği örgütsel yaratıcllk üzerinde daha etkilidir?. OPUS Uluslararası Toplum Araştırmalan Dergisi, 12, 167-192.

Zhang, S. X., Wang, Y., Rauch, A., ve Wei, F. (2020). Unprecedented disruption of lives and work: Health, distress and life satisfaction of working adults in China one month into the COVID-19 outbreak. Psychiatry Research, 112958.

Zhang, Y., Wang, S., Ding, W., Meng, Y., Hu, H., Liu, Z.1 ... ve Wang, M. (2020). Status and influential factors of anxiety depression and insomnia symptoms in the work resumption period of COVID-19 epidemic: A multicenter cross-sectional study. Journal of Psychosomatic Research, 110253.

Worldometers, (2020). Sağ lk Bakanlı̆̆ raporu. https://www.worldometers.info/coronavirus/?utm campaign=homeAdUOA?Si $\% 3 \mathrm{Ca} \% 20$ href

Our World in Data (2020). COVID-19: Government Response Stringency Index. https://ourworldindata.org/grapher/covid-stringency-index?tab=chart\&year=2020-05-07\&country= TUR Erișim Tarihi: 07.05.2020.

T.C. Sağlık Bakanlığı, (2020). Genel Bilgiler, Epidemiyoloji ve Tanı. https://covid19.saglik.gov.tr/TR-66337/genel-bilgiler-epidemiyoloji-ve-tani.html.

UNESCO, (2020). Education: From disruption to recovery. https://en.unesco.org/covid19/educationresponse. 


\section{Kaynakça Bilgisi / Citation Information}

Yiğitol, B. ve Büyükmumcu, S. (2021). Covid-19 korkusu, kişilik özellikleri, iş performansı ve işten ayrılma niyeti arasındaki yordayıcı ilişkilerin incelenmesi. OPUS-Uluslararası Toplum Araştırmaları Dergisi, 17(Pandemi Özel Say1s1), 3414-3447. DOI: 10.26466/opus.890502. 